Louisiana State University

LSU Digital Commons

8-1-2006

\title{
The northeastern Black Sea redox zone: Hydrochemical structure and its temporal variability
}

\author{
E. V. Yakushev \\ P.P.Shirshov Institute of Oceanology, Russian Academy of Sciences \\ V. K. Chasovnikov \\ P.P.Shirshov Institute of Oceanology, Russian Academy of Sciences \\ E. I. Debolskaya \\ P.P.Shirshov Institute of Oceanology, Russian Academy of Sciences
}

\author{
A. V. Egorov \\ P.P.Shirshov Institute of Oceanology, Russian Academy of Sciences \\ P. N. Makkaveev \\ P.P.Shirshov Institute of Oceanology, Russian Academy of Sciences
}

See next page for additional authors

Follow this and additional works at: https://digitalcommons.Isu.edu/biosci_pubs

\section{Recommended Citation}

Yakushev, E., Chasovnikov, V., Debolskaya, E., Egorov, A., Makkaveev, P., Pakhomova, S., Podymov, O., \& Yakubenko, V. (2006). The northeastern Black Sea redox zone: Hydrochemical structure and its temporal variability. Deep-Sea Research Part II: Topical Studies in Oceanography, 53 (17-19), 1769-1786.

https://doi.org/10.1016/j.dsr2.2006.05.019

This Article is brought to you for free and open access by the Department of Biological Sciences at LSU Digital Commons. It has been accepted for inclusion in Faculty Publications by an authorized administrator of LSU Digital Commons. For more information, please contact ir@lsu.edu. 


\section{Authors}

E. V. Yakushev, V. K. Chasovnikov, E. I. Debolskaya, A. V. Egorov, P. N. Makkaveev, S. V. Pakhomova, O. I. Podymov, and V. G. Yakubenko 


\title{
The northeastern Black Sea redox zone: Hydrochemical structure and its temporal variability
}

\author{
E.V. Yakushev ${ }^{a}$,*, V.K. Chasovnikov ${ }^{a}$, E.I. Debolskaya ${ }^{a}$, A.V. Egorov ${ }^{\text {, }}$, \\ P.N. Makkaveev ${ }^{\text {, }}$ S.V. Pakhomova ${ }^{\text {b }}$, O.I. Podymov ${ }^{a}$, V.G. Yakubenko ${ }^{\text {a }}$

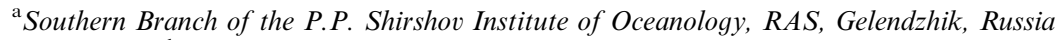 \\ ${ }^{\mathrm{b}}$ P.P. Shirshov Institute of Oceanology, RAS, Moscow, Russia
}

Received 1 June 2004; accepted 8 May 2006

Available online 6 September 2006

\begin{abstract}
Detailed studies of the vertical structure of hydrochemical parameters in the northeastern Black Sea near Gelendzhik are presented and discussed. This work is based on a set of systematic observations carried out in this region during $R / V$ "Akvanavt" and $R / V$ "Ashamba" cruises from 1997 to 2005 and also on data from previous studies from 1984 to 1997. The Black Sea region near Gelendzhik is far from the influences of the Bosporus input and Danube River inflow. Therefore, the vertical structure in this region is more stable compared to the western Black Sea and reflects "integrated," rather than local, changes of the Black Sea. Seasonal variations in the distribution of chemical parameters at the redox interface are connected to seasonal variations in hydrophysical processes and organic matter production. In winter, maxima of organic phosphorus and urea were absent in the vicinity of the onset of hydrogen sulfide. The concentrations of nitrate were lower in winter than in summer. Winter mixing in the anticyclone eddies led to reduced vertical gradients in the redox layer and to the disappearance of an upper phosphate minimum. Study of the interannual dynamics of oxygen concentrations in the Cold Intermediate Layer and anoxic waters boundary in the density field position revealed climaticscale changes that may be connected with changes in the North Atlantic Oscillation (NAO) index.
\end{abstract}

(C) 2006 Elsevier Ltd. All rights reserved.

Keywords: Black Sea; Biogeochemical cycle; Oxic/anoxic interface; Seasonal variability; Interannual variability; Macronutrients

\section{Introduction}

Black Sea is the largest meromictic basin in the world. Annual renovation of its surface waters occurs only down to depth of about 60-80 m, which is the depth of the Cold Intermediate Layer (CIL) $\left(\sigma_{\theta}=14.50 \mathrm{~kg} / \mathrm{m}^{3}\right)$. Turbulent diffusion controls the vertical flux below the CIL. This restriction of the supply of oxygen allows oxygen to become rapidly

\footnotetext{
*Corresponding author.

E-mail address: e_yakushev@yahoo.com (E.V. Yakushev).
}

consumed due to organic matter (OM) oxidation. Hydrogen sulfide first appears about $50 \mathrm{~m}$ below the depth of the CIL $(\sim 110-130 \mathrm{~m})$. Deeper water in the Black Sea below the CIL forms by variable mixing of the CIL with the high-salinity deep Bosporus outflow from the Marmara Sea (Murray et al., 1991). This mixing takes place on the continental shelf near the Bosporus.

Away from the SW region, influenced by the Bosphorus Plume, redox potential decreases gradually with increasing depth and water density. In the depth range where oxic conditions change to anoxic 
(the redox zone), oxidized and reduced chemical species interact. These processes occur in a predictable sequence depending on the changes in redox potential (Murray et al., 1995; Rozanov, 1995). The products of these reactions appear in the environment following the sequence of reactions. $\mathrm{OM}$, which is ultimately the main reducing agent in the redox zone (Rozanov, 1995), is transported from the euphotic zone as new production and is also generated by chemosynthesis in the redox zone (Sorokin, 2002). Water layers with sharply different chemical, biological and microbiological characteristics can be delineated in the Black Sea (Murray et al., 1995). Vertical distributions of reactants and products demonstrate that specific reactions may occur in layers as thin as $2-5 \mathrm{~m}$.

The sequence of reactions is characterized by diagnostic chemical distribution. These distributions display chemotropy - the correspondence of vertical chemical distributions to specific density levels (in accordance to barotropy-the correspondence of pressure and density levels). There have been numerous estimates of typical density levels of the onset of chemical species, depths of extrema and depths of change of vertical gradients (Vinogradov and Nalbandov, 1990; Codispoti et al., 1991; Lewis and Landing, 1991; Murray et al., 1995; Turgul et al., 1992; Rozanov et al., 2000; Konovalov, 2001; Chasovnikov, 2002).

One of the most interesting features of the redox zone of the Black Sea is the absence of direct contact of significant concentrations of oxygen and hydrogen sulfide. This suboxic layer (with formal boundaries of $10 \mu \mathrm{M}$ for oxygen and $0.3 \mu \mathrm{M}$ for hydrogen sulfide) was first described after $1988 \mathrm{R} / \mathrm{V}$ Knorr Expedition (Murray et al., 1989). Hydrogen sulfide was present in trace concentrations, and oxygen concentrations were near the detection limit of about 0.5-3 $\mu \mathrm{M}$ (Codispoti et al., 1991; Glazer et al., 2006) in an approximately 30-m layer.

A fine particle layer (FPL) also associated with the redox layer, and the light transmission minimum is observed near the hydrogen sulfide boundary (Volkov et al., 1997). OM decay occurs in the redox layer by different reactions (i.e., aerobic mineralization, denitrification, sulfate reduction), and redox processes are carried out both chemically and microbiologically (Millero, 1991; Tebo, 1991; Nealson and Stahl, 1997; Volkov et al., 1997). It is necessary to define the role of bacteria that govern redox reactions and consume inorganic nutrients (Sorokin, 2002), in ways that affect the vertical distributions of their organic forms (Sorokin, 2002; Coban-Yildiz et al., 2000; Yakushev et al., 2003). Since the cycles of all elements are interconnected, it is not possible to explain the distribution of any specific parameter without knowing its connection with the distribution of other parameters.

Over the past few decades the Black Sea has been seriously perturbed by intensive anthropogenic contamination (Konovalov and Murray, 2001). When observations from near the Danube delta in the 1980s were compared to data from the 1960s, Cociasu et al. (1996) found that some nutrients had increased (e.g., $\mathrm{NO}_{3}$ due to eutrophication) while others had decreased (e.g., Si due to dam construction or intensification of diatoms blooms). In addition to eutrophication, distributions in the Black Sea are influenced by variability in climate (Oguz et al., 2006). Changes in both the upper (Konovalov and Murray, 2001) and lower (Yakushev et al., 2001) boundaries of the suboxic layer have been observed.

The modern concept about the distributions and variability of the Black Sea oxic/anoxic interface have been based on several international expeditions to the Black Sea since the late 1980s. The majority of these expeditions took place in the southern and western parts of the Sea, which are significantly influenced by the influx from the Danube and the Bosporus Plume (Codispoti et al., 1991; Lewis and Landing, 1991; Tebo, 1991; Luther et al., 1991; Murray et al., 1995; Ivanov et al., 1999; Konovalov et al., 2003). These studies took place in different years and different seasons, and it is sometimes difficult to determine what controls the observed spatial and temporal variability.

Recent studies in offshore waters, distant from the Bosporus, have revealed changes in the characteristics of chemotropy (Yakushev et al., 2003; Glazer et al., 2006) in different seasons and/or different regions of the Sea. Such changes are determined by the combined influence of a complex set of processes that are characterized by different climatic, seasonal and synoptic scales. To estimate their relative roles, it is necessary to analyze systematic observations of temporal and spatial variability.

For these reasons it is better to use observations from the northeastern Black Sea (NE BS), a region far from the influence of the Bosporus Plume and Danube River inflow. Compared to the southern and western parts of the sea, there is less difference of the redox layer structure between the central 
(Eastern Gyre) and coastal region. There is better correspondence between the chemical structure features and the density levels throughout this region, and intrusions from remote sources into the redox zone are not observed. Therefore, (1) the vertical structure in this region is more stable compared to the other regions of the Black sea and (2) changes of this structure reflect "integrated", rather than local, changes of the Sea.

This study presents the data collected in the NE BS, where an intensive time series of observations has been observed. This is a unique dataset in the Black Sea. There are very few such time series available to document seasonal/interannual variability at the same site. The goal of this paper is to describe the details of the hydrochemical structure of the redox zone in this region and to determine the temporal variability on seasonal and interannual time scales.

\section{Materials and methods}

\subsection{Study area}

The location of the region studied and an example of the surface currents is presented in Fig. 1. The NE BS is influenced by the rim current that is directed to the northwest parallel to the coast line. The intensity of this current changes seasonally and interannualy (Zatsepin et al., 2002). Anticyclonic eddies are usually observed between this current and the coast. These anticyclones also migrate to the northwest. The distributions of chemical and biological characteristics are connected to the position of the rim current frontal zone (Chasovnikov, 2002).

\subsection{Sampling and analysis}

This work is based on observations carried out in the NE BS during $R / V$ "Akvanavt" and $R / V$ "Ashamba" cruises from 1997 to 2005 and also on data from previous studies on the other vessels from 1984 to 1997 (Table 1).

In the cruises devoted to the redox interface studies, the sampling in the suboxic layer $\left(\sigma_{\theta}=\right.$ $16.20-15.80 \mathrm{~kg} / \mathrm{m}^{3}$ and shallower) was performed at 2-3 m intervals. During multiple day cruises (aboard $R / V$ "Akvanavt"), samples were processed aboard ship and during the 1-day cruises (aboard $R / V$ "Ashamba" or $R / V$ "Akvanavt") samples were processed in the coastal laboratory within
1-2 $\mathrm{h}$ of sampling. These studies were performed periodically and cover all the seasons.

The following parameters were measured: dissolved oxygen, $\mathrm{pH}$, alkalinity, phosphate, total phosphorus, silicate, nitrate, nitrite, ammonium, urea, total nitrogen, hydrogen sulfide, manganese, iron and methane. Water samples for chemical measurements were collected with 5-L Niskin bottles on a rosette equipped with a Sea Bird CTD probe.

Dissolved oxygen analyses were performed using the classic Winkler method with a 30-ml Jencons Digitrate automatic burette. In addition to a correction for the blank, we also corrected for the oxygen content in the reagents (Hansen, 1999). The accuracy of Winkler technique was $0.02 \mathrm{ml} / \mathrm{L}$ $(0.9 \mu \mathrm{M})$, the detection limit was about $0.06 \mathrm{ml} / \mathrm{L}$ $(2.7 \mu \mathrm{M})$.

$\mathrm{pH}$ was measured by glass electrode and determined on the NBS scale with a pH-meter "I-500" (produced by NPKF “Aquilon”, Russia). The precision was about $0.01 \mathrm{pH}$ units.

Alkalinity samples were collected in 250-ml glass bottles. Total alkalinity was determined in the coastal laboratory by direct titration with hydrochloric acid according to Bruevich's modification (Bordovskiy and Chernyakova, 1992). The titration was conducted with constant venting with $\mathrm{CO}_{2}$-free air to $\mathrm{pH}$ value of 5.45 . The precision of this technique was about $2 \mu \mathrm{eq} / \mathrm{kg}$.

Phosphate was determined by the method of Koroleff (Hansen and Koroleff, 1999). Absorbance was measured at $885 \mathrm{~nm}$ in a $50-\mathrm{mm}$ cell.

For silicate, we used the method by Koroleff (1972) based on the formation of B-1:12 silico molybdic acid and its partial reduction to a blue heteropoly acid. Absorbance was measured at $880 \mathrm{~nm}$ with a $10-\mathrm{mm}$ cuvette.

Nitrite was measured with sulfanilamide and $N-1$ naphthylethylendiamine dihydrochloride (Hansen and Koroleff, 1999). Nitrate was converted to nitrite using $\mathrm{Cu}-\mathrm{Cd}$ columns. Absorbance was measured at $543 \mathrm{~nm}$ in a $50-\mathrm{mm}$ cell. After 2004, nitrate was measured with AA "Brann-Luebbe" in accordance to the producer's recommendations.

Ammonium was determined by the phenol-hypochlorite reaction (Solorzano, 1969). The reagents (phenol and hypochlorite solutions) were added on deck in order to avoid contamination of $\mathrm{NH}_{3}$ from the air inside the ship.

Urea was measured photometrically with diacetylmonooxim and semicarbazid (Sapozhnikov et al., 

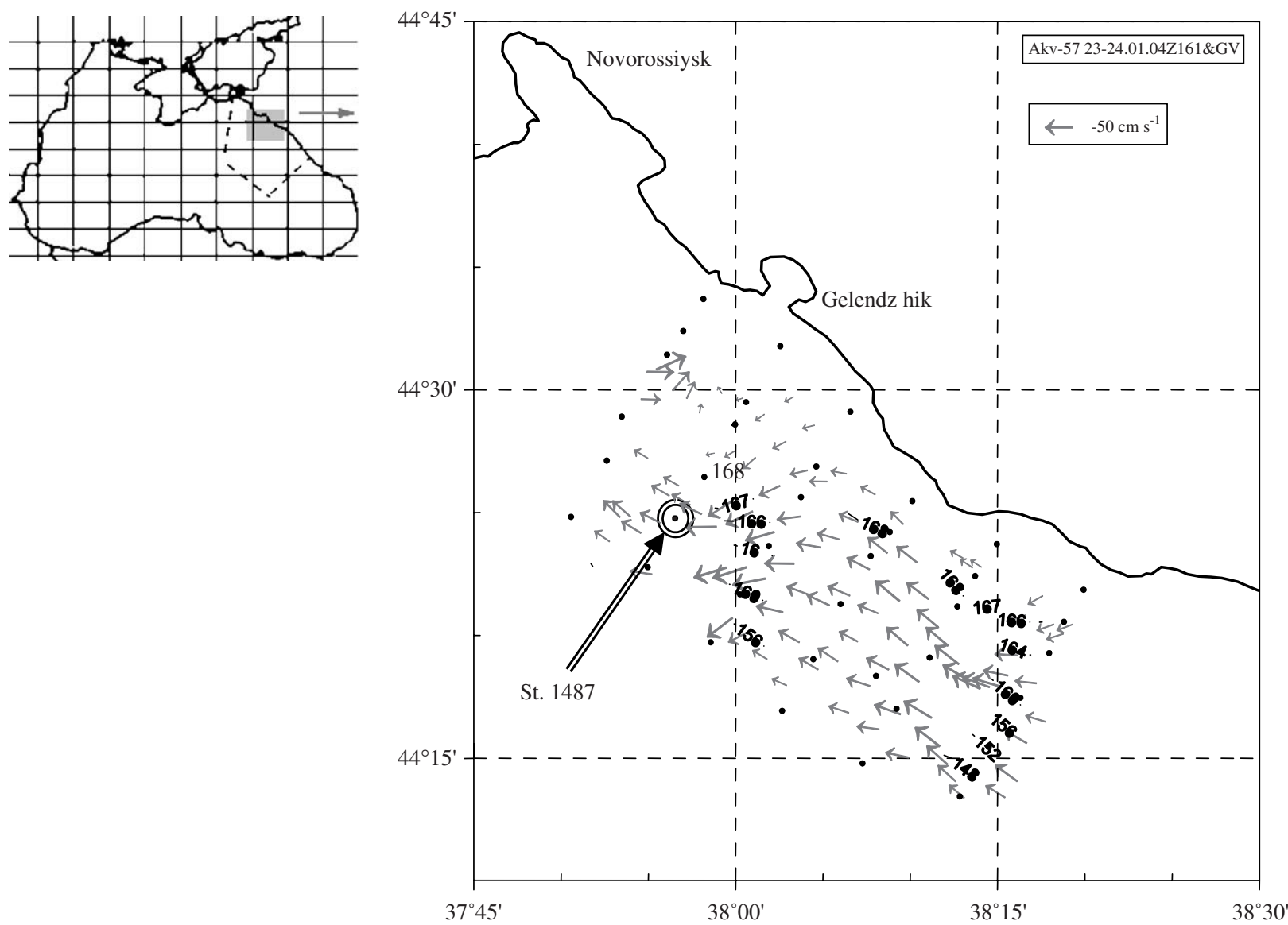

Fig. 1. Region of studies (bounded by a dashed line) near Gelendzhik, Russia and the position of station 1487 in a velocity field of the $R / V$ "Akvanavt" survey in January 24-25, 2004 calculated by the geostrophic method.

Table 1

List of expeditions with chemical measurements in the redox layer in the Northeastern Black Sea

\begin{tabular}{|c|c|c|}
\hline Vessel, Cruise \# & Date & Content of work \\
\hline$R / V$ "Vityaz" & 1984, April 22-May 30 & NE, SE and western coast of the BS \\
\hline$R / V$ "Rift" & 1986, May 19-June 29 & A few stations near Gelendzhik and Bulgarian coast \\
\hline$R / V$ "Vityaz" & 1988, March 07-25 & Several stations in NW and central part of the BS \\
\hline$R / V$ "Yantar" & 1989, February 09-March 23 & Polygon survey near( $\sim 25$ miles rad.) Gelendzhik and Novorossiysk \\
\hline$R / V$ "Akvanavt" & 1989, February 09-15 & Polygon survey near( $\sim 20$ miles rad.) Gelendzhik \\
\hline$R / V$ "Akvanavt" & 1989, March 09-23 & Polygon survey near( $\sim 25$ miles rad.) Novorossiysk and Gelendzhik \\
\hline$R / V$ "Akvanavt" & 1989, May 26-June 02 & Polygon survey near( $\sim 20$ miles rad.) Gelendzhik \\
\hline$R / V$ "Dmitry Mendeleev" & 1989, July 23-September 09 & NE, NW and southern parts of the BS \\
\hline$R / V$ "Akvanavt" & 1989, August 02-14 & Polygon survey near( $\sim 25$ miles rad.) Novorossiysk and Gelendzhik \\
\hline$R / V$ "Akvanavt" & 1989, November $02-15$ & Polygon survey near NE coast of the BS \\
\hline$R / V$ “Akvanavt” & 1990, February 20-22 & A few stations near ( $\sim 10$ miles rad.) Novorossiysk and Gelendzhik \\
\hline$R / V$ "Profsoyuz" & 1990, August 15-19 & Polygon survey near( $\sim 25$ miles rad.) Gelendzhik and Novorossiysk \\
\hline$R / V$ "Vityaz" & 1991, February 11-April 04 & Central, NW and SE parts of the BS \\
\hline$R / V$ "Rift" & 1991, June $10-18$ & Polygon survey near( $\sim 30$ miles rad.) Gelendzhik and Novorossiysk \\
\hline$R / V$ "Vityaz" & 1991, August 17-23 & A few stations in the eastern, central and NW part of the BS \\
\hline$R / V$ "Akvanavt" & 1994, September 11-19 & Polygon survey in NE part of the BS \\
\hline$R / V$ "Akvanavt" & 1994, September 30-October 05 & Polygon survey near $(\sim 30$ miles rad. $)$ NE coast of the BS \\
\hline$R / V$ "Akvanavt" & 1995, March 19-28 & Polygon survey in NE part of the BS \\
\hline$R / V$ "Donuzlav" & 1995, July 23-26 & cross-section "Gelendzhik-Eastern Gyre" \\
\hline
\end{tabular}


Table 1 (continued)

\begin{tabular}{|c|c|c|}
\hline Vessel, Cruise \# & Date & Content of work \\
\hline$R / V$ "Yantar" & 1996, June 25-July 06 & Polygon survey in NE part of the BS \\
\hline$R / V$ "Yuzhmorgeo" & 1996, September 01-08 & Polygon survey near( $\sim 10$ miles rad.) NE coast of the BS \\
\hline$R / V$ "Akvanavt" & 1997, November $12-17$ & cross-section "Gelendzhik-Eastern Gyre" \\
\hline$R / V$ "Akvanavt" & 1998, April 07-09 & cross-section "Gelendzhik -Eastern Gyre" \\
\hline$R / V$ "Akvanavt" & 1999, February 13-16 & cross-section "Gelendzhik_Eastern Gyre" \\
\hline$R / V$ "Akvanavt" & 1999, April 08-09 & cross-section "Gelendzhik -Eastern Gyre", \\
\hline$R / V$ "Akvanavt" & 1999, June 10-11 & cross-section "Gelendzhik-Eastern Gyre" \\
\hline$R / V$ "Akvanavt" & 1999, September $25-30$ & Polygon survey in NE part of the BS \\
\hline$R / V$ "Akvanavt" & 1999, October $04-07$ & cross-section "Tuapse-Eastern Gyre" \\
\hline$R / V$ "Akvanavt" & 1999, October $14-17$ & cross-section "Gelendzhik-Eastern Gyre" \\
\hline$R / V$ "Akvanavt" & 1999, October 21-26 & cross-section "Gelendzhik -Eastern Gyre" \\
\hline$R / V$ "Akvanavt" & 1999, November 23-December 07 & Studies near( $\sim 3$ miles rad.) Gelendzhik \\
\hline$R / V$ "Akvanavt" & 1999, December 24-26 & cross-section "Gelendzhik-Eastern Gyre" \\
\hline$R / V$ "Akvanavt" & 2000, February 29-March 02 & cross-section "Gelendzhik -Eastern Gyre" \\
\hline$R / V$ "Akvanavt" & 2000, April 07-08 & cross-section "Gelendzhik - Eastern Gyre" \\
\hline$R / V$ "Akvanavt" & 2000, October $31-$ November 04 & Polygon survey in NE part of the BS \\
\hline$R / V$ "Akvanavt" & 2000, November $17-20$ & Polygon survey in NE part of the BS \\
\hline$R / V$ "Akvanavt" & 2000, November 30-December 04 & cross-section "Sochi-Eastern Gyre" \\
\hline$R / V$ "Akvanavt" & 2000, December 20-22 & cross-section "Gelendzhik - Eastern Gyre" \\
\hline$R / V$ "Akvanavt" & 2001, April 03-06 & cross-section "Gelendzhik - Eastern Gyre" \\
\hline$R / V$ "Akvanavt" & 2001, April 25-29 & cross-section "Gelendzhik - Eastern Gyre" \\
\hline$R / V$ "Akvanavt" & 2001, June $10-11$ & cross-section "Gelendzhik - Eastern Gyre" \\
\hline$R / V$ "Akvanavt" & 2001, July 29 & A station near ( $\sim 7$ miles) from Gelendzhik \\
\hline$R / V$ "Akvanavt" & 2001, August 20 & A station near ( $\sim 7$ miles) Gelendzhik \\
\hline$R / V$ "Akvanavt" & 2001, September 02 & Few stations near( $\sim 5$ miles rad. $)$ Gelendzhik \\
\hline$R / V$ "Akvanavt" & 2001, September $15-19$ & cross-section "Gelendzhik -Eastern Gyre" \\
\hline$R / V$ "Akvanavt" & 2001, September $28-30$ & cross-section "Gelendzhik_Eastern Gyre" \\
\hline$R / V$ "Akvanavt" & 2001 , October 6-12 & Polygon survey in NE-eastern part of the BS \\
\hline$R / V$ "Akvanavt" & 2001 , October $22-23$ & cross-section "Gelendzhik -Eastern Gyre" \\
\hline$R / V$ "Akvanavt" & 2001, November 29-December 04 & Polygon survey in NE part of the BS \\
\hline$R / V$ "Akvanavt" & 2002, March 15 & A station near ( $\sim 3$ miles) Gelendzhik \\
\hline$R / V$ "Akvanavt" & 2002, March 28-30 & cross-section "Gelendzhik - Eastern Gyre" \\
\hline$R / V$ "Akvanavt" & 2002, May $18-20$ & cross-section "Gelendzhik $\sigma$ Eastern Gyre" \\
\hline$R / V$ "Akvanavt" & 2002, May 24-30 & Polygon survey in NE part of the BS \\
\hline$R / V$ "Akvanavt" & 2002, July 06-11 & cross-section in the Eastern Gyre \\
\hline$R / V$ "Akvanavt" & 2002, August 23-24 & Few station $\sim 30$ miles from Gelenzhik \\
\hline$R / V$ "Ashamba" & 2003, July 02 & A station near ( $\sim 3$ miles) Gelendzhik \\
\hline$R / V$ "Ashamba" & 2003, August 29 & A station near ( $\sim 3$ miles) Gelendzhik \\
\hline$R / V$ "Ashamba" & 2003 , September 10 & A station near ( $\sim 3$ miles $)$ Gelendzhik \\
\hline$R / V$ "Akvanavt" & 2004, January 26 & A station near ( $\sim 20$ miles) Novorossiysk \\
\hline$R / V$ "Akvanavt" & 2004, May 11-14 & cross-section "Gelendzhik -Eastern Gyre" \\
\hline$R / V$ "Akvanavt" & 2004, June $02-06$ & Polygon survey in NE part of the BS \\
\hline$R / V$ "Akvanavt" & 2004, June 21-25 & cross-section "Gelendzhik - Eastern Gyre" \\
\hline$R / V$ "Akvanavt" & 2004, July 14 & cross-section "Tuapse -Eastern Gyre" \\
\hline$R / V$ "Akvanavt" & 2004 , July $16-17$ & A station near ( $\sim 5$ miles) Gelendzhik \\
\hline$R / V$ "Akvanavt" & 2004, September $09-12$ & Studies in the NE part of the BS \\
\hline$R / V$ "Akvanavt" & 2004, December 08-09 & cross-section "Gelendzhik-Eastern Gyre" \\
\hline
\end{tabular}

1988). This technique can be applied for concentrations from 0.1 to $10 \mu \mathrm{g}$ at $/ \mathrm{L}$ and has a precision of $4.3 \%$ at concentration of $2 \mu \mathrm{g}$ at/L.

Total phosphorus was determined by digestion with sodium persulfate in a water bath at $100^{\circ} \mathrm{C}$. The Valderrama technique (digestion in an autoclave) was used for analysis of total nitrogen.
Organic forms of phosphorus and nitrogen were estimated as the difference between the total and inorganic forms (phosphate for phosphorus and nitrate, nitrate and ammonium for nitrogen).

Two techniques were used for determination of hydrogen sulfide: low concentrations (less than $30 \mu \mathrm{M} \mathrm{H} \mathrm{H}_{2} \mathrm{~S}$ ) in the upper part of anoxic zone were 
determined photometrically with paraphenilendiamin, while higher concentrations were determined by iodometric titration (Volkov and Zhabina, 1990; Bordovskiy and Chernyakova, 1992).

Samples for methane were taken from Niskin bottles into $120-\mathrm{ml}$ glass bottles using silicone tubing. A head space of about $12 \mathrm{ml}$ was left unfilled in each bottle. The bottles were made gas tight using a screw lid having a rubber membrane. Samples were shaken and left to establish temperature and gas phase equilibrium. The gas phase was taken for analysis by a syringe through the rubber membrane and a hole in the lid. The methane content in the gas phase was determined by gas chromatography (LHM-80) with flame-ionization detection. Methane concentrations in the water samples were calculated following Bol'shakov and Egorov (1987), assuming that the initial methane content in the gas phase was equal to that in the atmosphere and had a value of $1.8 \mathrm{ppm}$. The precision of this method calculated from results of parallel measurements was $\pm 2 \%$ and the detection limit was $0.2 \mathrm{nM}$.

Iron(II) was analyzed using the iron(II)-ferrozine complex (Stookey, 1970). Total iron was determined after reducing iron(III) to iron(II) using ascorbic acid. Iron(III) concentration was calculated by the difference between total iron and iron(II). For total iron determinations an aliquot $(20 \mathrm{ml})$ of filtered water, $0.5 \mathrm{ml}$ of ascorbic acid, $0.5 \mathrm{ml}$ of an acetate buffer solution and $0.5 \mathrm{ml}$ of the ferrozine solution were placed in 20- $\mathrm{ml}$ tubes. The solutions were heated in a water bath $\left(80^{\circ} \mathrm{C}\right)$ for $30 \mathrm{~min}$. After cooling the solutions to room temperature, their absorbance was measured at $562 \mathrm{~nm}$ using a $5 \mathrm{~mm}$ cell. For iron(II) determinations, the procedure described above was used but without the ascorbic acid solution.

Formaldoxime-based technique was used for manganese determination (Peshkova and Ovsyannikova, 1937; Brewer and Spencer, 1971).

\subsection{Data}

The data obtained during all the expeditions (Table 1) were calculated and used for statistical calculations. A problem-oriented database for the redox layer of the Black Sea was developed to aid in these calculations (Podymov, 2005). A summary of cruises (http://sbsio.coast.ru/chemist/exped_e.html) represents the set of equitype arrays with the results of hydrophysical and hydrochemical measurements, and the position and date at each station. The data can be available on request (e_yakushev@yahoo. com). The data arrays are written in a standard format of an electronic worksheet. The majority of the more than 1400 stations included in the database contain field observations from the northeastern part of the Black Sea from 1984 till today. A program was written to set specific criteria of data selection and loading, and to add new functions for solving specific tasks (Podymov, 2005). This database was used to perform the calculations described below.

\section{Results}

The examples of typical distributions that we observe in the NE BS in summer and winter are presented in Figs. 2 and 3, respectively.

The summer distributions (Fig. 2) were characterized by a $10-20 \mathrm{~m}$ surface-mixed layer with high $\left(25-26^{\circ} \mathrm{C}\right)$ temperature. This layer was characterized by minimum concentrations of nutrients $(0.01-$ $0.05 \mu \mathrm{M} \mathrm{PO}, 0.27-0.70 \mu \mathrm{M} \mathrm{NO}, 2.5-3.9 \mu \mathrm{M} \mathrm{Si}$ ), maximal $\mathrm{pH}$ values and significant concentrations of oxygen $250 \mu \mathrm{M}$. Oxygen increased to $290-300 \mu \mathrm{M}$ in the upper part of the CIL. Below the CIL, sharp increases in concentrations of phosphate and nitrate and a decrease in oxygen were observed.

In winter (Fig. 3), the surface $0-40 \mathrm{~m}$ layer was characterized by low temperatures $\left(9-10.2^{\circ} \mathrm{C}\right)$ and by a slight decrease in temperature with depth. The vertical distribution of temperature and salinity revealed several 5-m-lenses of uniform density water at 135 and $165 \mathrm{~m}$ which were below the depth of the CIL $(\sim 80 \mathrm{~m})$. High and uniform concentrations of dissolved oxygen (304-308 $\mu \mathrm{M})$, high $\mathrm{pH}$ values and low concentrations of nutrients $\left(0.10-0.18 \mu \mathrm{M} \mathrm{PO}_{4}\right.$, $0.25-0.5 \mu \mathrm{M} \mathrm{NO}_{3}, 3.5-3.8 \mu \mathrm{M} \mathrm{Si}$ ) were observed in the surface layer $(0-40 \mathrm{~m})$. As opposed to the warm periods of the year (Fig. 2), maxima of organic phosphorus, organic nitrogen and urea were not observed at the lower boundary of this layer, in the vicinity of the core of CIL $\left(\sigma_{\theta}=14.5 \mathrm{~kg} / \mathrm{m}^{3}\right)$, where phosphate, nitrate and silicate begin to increase.

Maximum concentrations of nitrate $(\sim 110 \mathrm{~m}$ $\left.\sigma_{\theta}=15.25 \mathrm{~kg} / \mathrm{m}^{3}\right)$ in winter reached $2-2.5 \mu \mathrm{M}$ (Fig. 3), which was significantly less than values we observed during summer (about $4.5-5 \mu \mathrm{M}$ ). The upper phosphate maximum observed in summer (Fig. 2) at $\sigma_{\theta}=15.65 \mathrm{~kg} / \mathrm{m}^{3}$ was absent, and instead phosphate increased monotonously with depth. The summer vertical structure of phosphate with a 

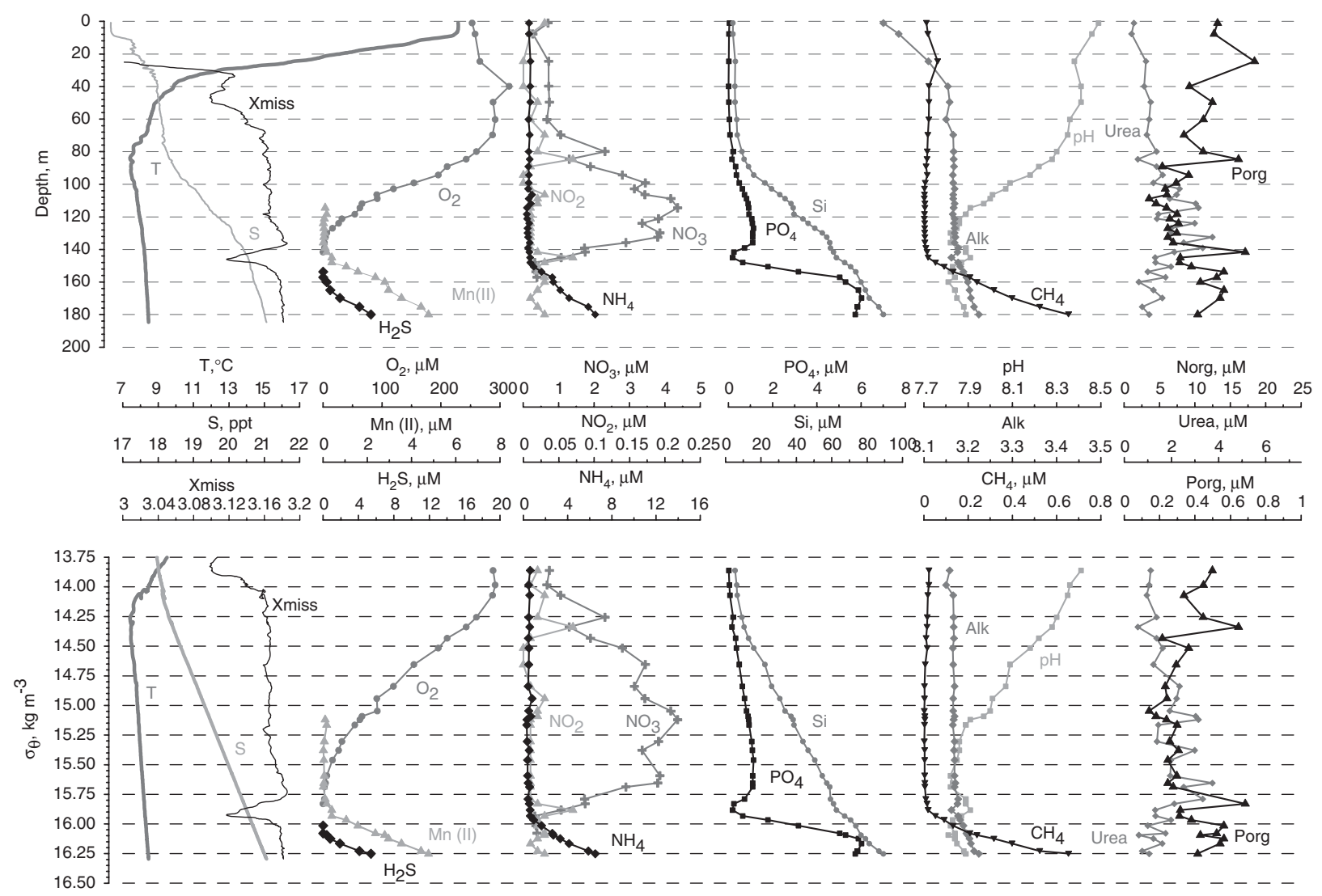

Fig. 2. Vertical distribution of temperature $(T)$, salinity $(S)$, density $\left(\sigma_{\theta}\right)$, transmission $(\mathrm{Xmiss})$, dissolved oxygen $\left(\mathrm{O}_{2}\right)$, hydrogen sulfide $\left(\mathrm{H}_{2} \mathrm{~S}\right)$, total manganese $(\mathrm{Mn})$, silicate $(\mathrm{Si})$, nitrate $\left(\mathrm{NO}_{3}\right)$, nitrite $\left(\mathrm{NO}_{2}\right)$, ammonia $\left(\mathrm{NH}_{4}\right)$, urea $($ Urea $)$, phosphate $(\mathrm{PO})$, organic phosphorus (Porg), pH, total alkalinity (Alk) and methane $\left(\mathrm{CH}_{4}\right)$ at a station near Gelendzhik (St. 1331, July 2002). Concentrations of chemical parameters are in $\mu \mathrm{M}$. Distributions are plotted versus depth in the top and versus density at the bottom.

shallow phosphate minimum was absent. Instead, there was an increase in the vertical gradient of phosphorus at about $\sigma_{\theta}=15.90 \mathrm{~kg} / \mathrm{m}^{3}$. Nitrate disappeared at the same density $\left(\sigma_{\theta}=16.00 \mathrm{~kg} / \mathrm{m}^{3}\right)$, as has been observed previously in NE BS. A deeper maximum of nitrite was observed both in winter and summer with value of $0.05 \mu \mathrm{M}$, but the background concentrations were higher in winter than in summer (Figs. 2 and 3).

Hydrogen sulfide first appeared at $\sigma_{\theta}=16.10 \mathrm{~kg} / \mathrm{m}^{3}$ in both winter and summer, but in winter its boundary was more gradual than in summer. The onset of ammonium and manganese(II) were observed at the same density $\left(\sigma_{\theta}=15.90 \mathrm{~kg} / \mathrm{m}^{3}\right)$ in winter and summer. Methane started to increase at $\sigma_{\theta}=15.85-15.90 \mathrm{~kg} / \mathrm{m}^{3}$.

The distribution of alkalinity was characterized in summer by uniform values from the upper mixed layer $(0-40 \mathrm{~m})$ down to $\sigma_{\theta}=15.90 \mathrm{~kg} / \mathrm{m}^{3}(3170$ $3190 \mu \mathrm{M})$. Below this density increasing values were observed (Fig. 2). In winter (Fig. 3), the distribution of alkalinity was characterized by more variability. A small increase in alkalinity was observed from the CIL $(3200-3230 \mu \mathrm{M})$ to the sulfide boundary $(3250-3270 \mu \mathrm{M})$. Similar changes between summer and winter in absolute values and pattern of distribution were seen in salinity (Figs. 2 and 3).

The vertical distribution of the organic phosphorus was characterized by abrupt increase in concentration at $\sigma_{\theta}=15.75 \mathrm{~kg} / \mathrm{m}^{3}$ from $0.2-0.4$ to $0.3-0.5 \mu \mathrm{M}$ in summer and from $0.1-0.2$ to $0.3-0.4 \mu \mathrm{M}$ in winter (Figs. 2 and 3). In winter we observed a decrease in total organic nitrogen from $10-14 \mu \mathrm{M}$ at $\sigma_{\theta}=15.75 \mathrm{~kg} / \mathrm{m}^{3}$ to $8-10 \mu \mathrm{M}$ at $\sigma_{\theta}=15.90 \mathrm{~kg} / \mathrm{m}^{3}$ (Fig. 2).

The absence of a urea maximum in the vicinity of the $\mathrm{H}_{2} \mathrm{~S}$ onset was another distinctive characteristic of the winter period. The background concentrations of urea were lower in winter than in summer ( $1 \mu \mathrm{M}$ compared with $2-4 \mu \mathrm{M})$. 

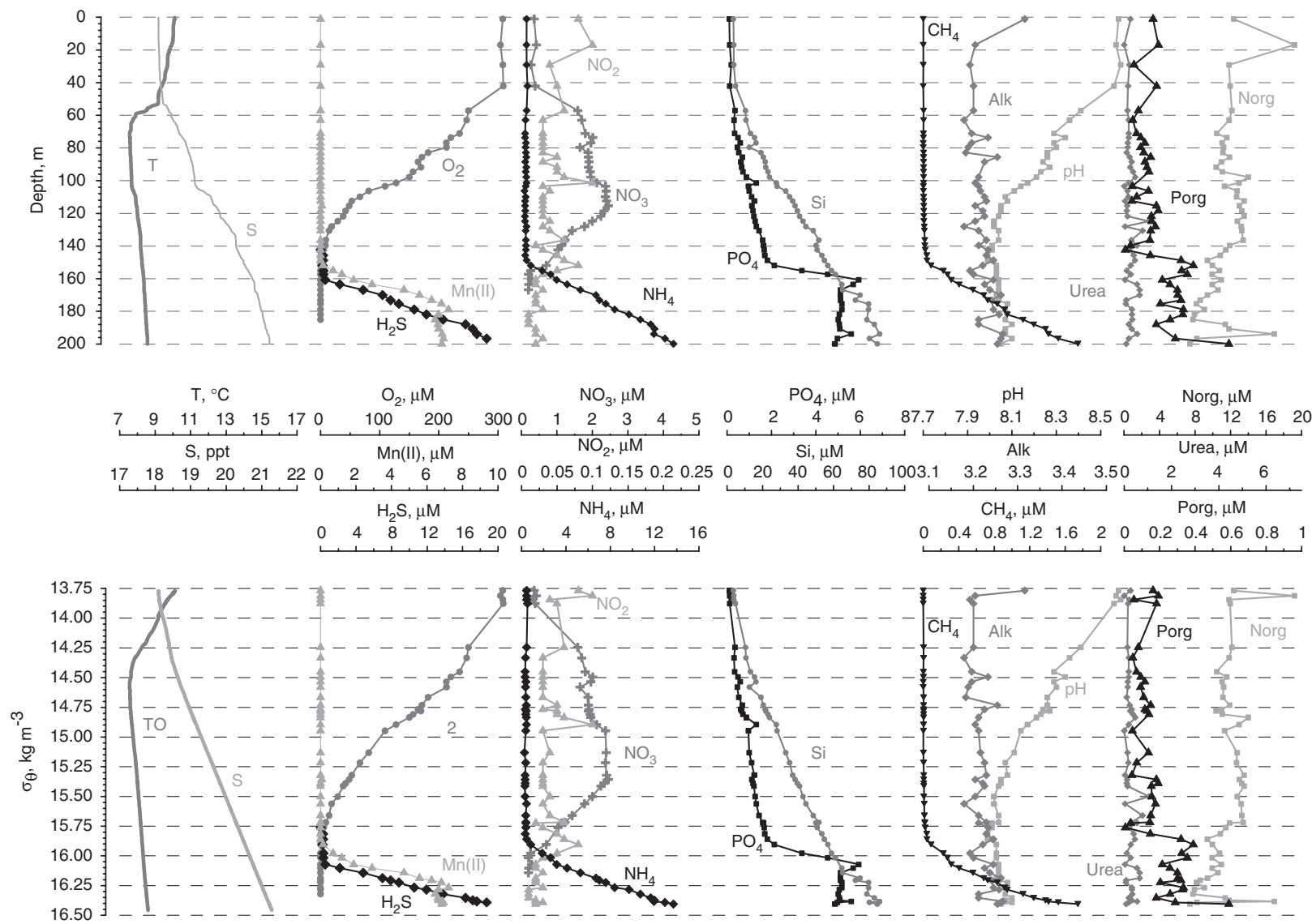

Fig. 3. Vertical distribution of temperature $(T)$, salinity $(S)$, density $\left(\sigma_{\mathrm{T}}\right)$, oxygen $\left(\mathrm{O}_{2}\right)$, hydrogen sulfide $\left(\mathrm{H}_{2} \mathrm{~S}\right)$, total manganese $(\mathrm{Mn})$, silicate $(\mathrm{Si})$, nitrate $\left(\mathrm{NO}_{3}\right)$, nitrite $\left(\mathrm{NO}_{2}\right)$, ammonia $\left(\mathrm{NH}_{4}\right)$, urea (Urea), phosphate $\left(\mathrm{PO}_{4}\right)$, organic phosphorus $(\mathrm{Porg})$, pH, total alkalinity (Alk) and methane $\left(\mathrm{CH}_{4}\right)$ at a station near Gelendzhik (St. 1487, January 2004). Concentrations of chemical parameters are in $\mu \mathrm{M}$. Concentrations of chemical parameters are in $\mu \mathrm{M}$. Distributions are plotted versus depth in the top versus density at the bottom.

\section{Discussion}

In general, the chemical structure of the redox layer in the NE BS corresponds to that observed in the central part of the Black Sea. The thickness of the suboxic zone also varies in the depth units, but remains constant versus density. These density values (Table 2) correspond well to those observed in the central and western regions. The positions of onset levels, maximum values of chemical parameters agree well with those observed previously in the central regions (Murray et al., 1995) (Table 2). In the NE BS, the depth of hydrogen sulfide onset varies in the coastal region from 100 to $180 \mathrm{~m}$ and from 70 to $100 \mathrm{~m}$ in the Eastern Gyre. The first appearance of hydrogen sulfide is usually observed to deepen in winter and in the anticyclonic eddies. Having this good record for the past years (Table 1) makes this site ideal for studying the temporal evolution of the Black Sea.

On the basis of the NE BS expedition data from 1999 to 2002, we have estimated the statistical quartile analysis of these characteristics (Fig. 4). The distributions of hydrochemical features in the shallower layers of the water column are characterized by greater variability. That reflects the influence of seasonal variability and eddies that play a greater role in the upper layers of the suboxic zone (Chasovnikov, 2002).

In comparison to the western and southernwestern Black Sea, which can be described by pronounced water intrusions, the NE BS redox layer is characterized by a spatially and temporally stable hydrophysical and chemical vertical structure. We do not observe the same degree of variability at the same density levels, and this 
Table 2

Characteristics of hydrochemical structure in the density field $\left(\mathrm{kg} \mathrm{m}^{3}\right)$ in the Northeastern Black Sea in comparison to the Central and Western Black Sea

\begin{tabular}{lll}
\hline $\begin{array}{l}\text { Characteristics of hydrochemical } \\
\text { structure }\end{array}$ & $\begin{array}{l}\text { Central and Western Black Sea (Murray } \\
\text { et al., 1995) }\end{array}$ & $\begin{array}{l}\text { Northeastern Black Sea (Chasovnikov, } \\
\text { 2002) }\end{array}$ \\
\hline Maximum of $\mathrm{NO}_{3}$ & 15.40 & $15.27-15.45$ \\
$\mathrm{NO}_{3}<0.2 \mu \mathrm{M}$ & 15.95 & $15.85-15.95$ \\
Maximum of $\mathrm{NO}_{2}$ & 15.85 & $15.85-15.95$ \\
Onset of $\mathrm{NH}_{4}\left(\mathrm{NH}_{4}<0.2 \mu \mathrm{M}\right)$ & 15.95 & $15.92-15.98$ \\
Upper maximum of $\mathrm{PO}_{4}$ & 15.50 & $15.41-15.63$ \\
Minimum of $\mathrm{PO}_{4}$ & 15.85 & $15.90-15.96$ \\
Lower maximum of $\mathrm{PO}_{4}$ & 16.20 & $16.19-16.21$ \\
Onset of $\mathrm{Mn}^{2+}$ & 15.85 & $15.80-15.90$ \\
Onset of $\mathrm{H}_{2} \mathrm{~S}(>1 \mu \mathrm{M})$ & $16.15 \pm 0.05$ & $16.08-16.14$ \\
\hline
\end{tabular}

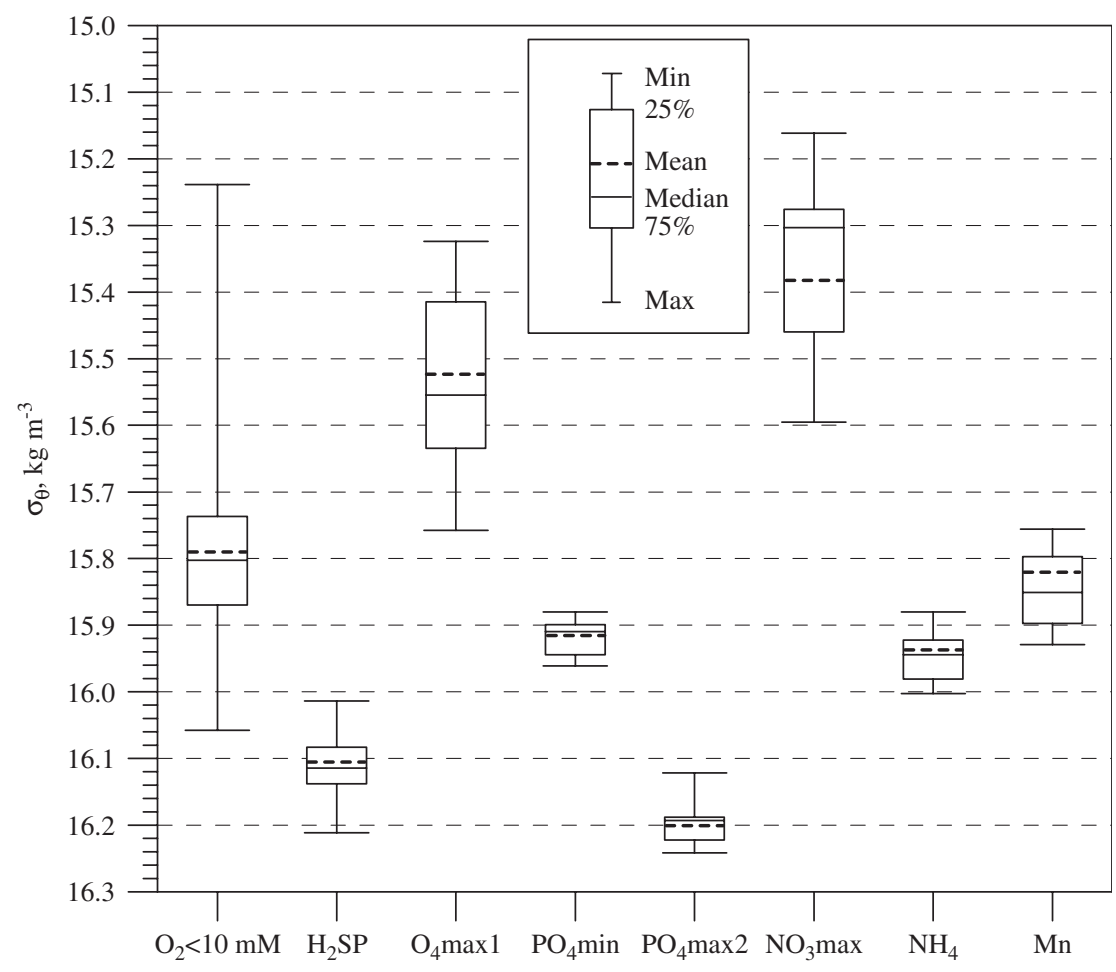

Fig. 4. Characteristic density values of hydrochemical parameters: decrease of $\mathrm{O}_{2}<10 \mathrm{mM}$, onsets of $\mathrm{H}_{2} \mathrm{~S}, \mathrm{NH}_{4}$ and $\mathrm{Mn}$, maximum of $\mathrm{NO}_{3}\left(\mathrm{NO}_{3} \mathrm{max}\right)$, minimum of $\mathrm{PO}_{4}\left(\mathrm{PO}_{4} \mathrm{~min}\right)$, shallow $\left(\mathrm{PO}_{4} \mathrm{max} 1\right)$ and deep $\left(\mathrm{PO}_{4} \mathrm{max} 2\right) \mathrm{PO}_{4}$ maxima. Results of the quartile analysis ("Box-Whisker" plots: $x_{\min }, x_{0.25}, x_{0.50}, x_{0.75}, x_{\max }$ ) for the 1999-2000 NE Black Sea data.

reflects the absence of significant lateral transport of matter.

The vertical redox hydrochemical structure of this region is determined first of all by vertical exchange. It is possible to assume the following hypothesis for the functioning of the different layers (Yakushev et al., 2002).

Density layer $\sigma_{\theta}=15.50-15.70 \mathrm{~kg} / \mathrm{m}^{3}$ : In the upper part of the redox zone, concentrations of dissolved oxygen decrease to $15-20 \mu \mathrm{M}$, and its vertical gradient abruptly decreases and becomes equal to that of nitrate (Fig. 5). In this layer, nitrate, instead of oxygen, becomes the main oxidizer. Nitrate is rapidly consumed and its concentrations decrease rapidly. The reason for the decrease in the vertical gradient of oxygen is because there is a decrease in the rate of reactions that consume oxygen. 


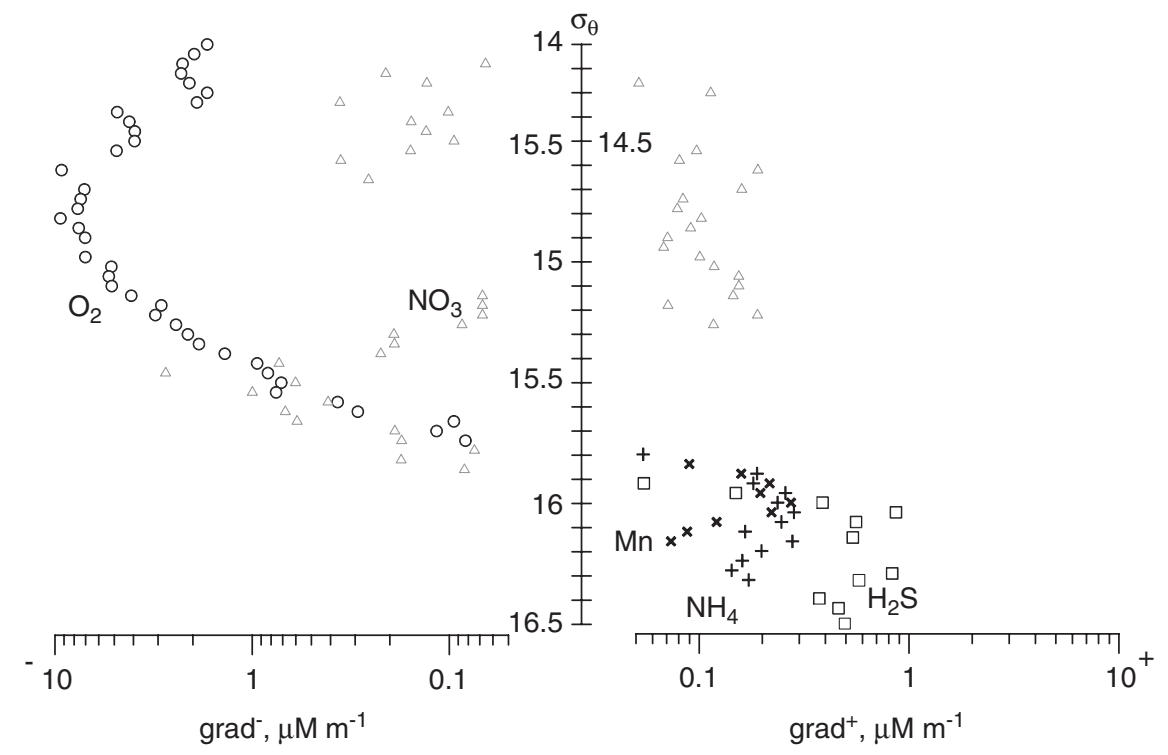

Fig. 5. Mean values of vertical gradients of $\mathrm{Mn}, \mathrm{NH}_{4}, \mathrm{H}_{2} \mathrm{~S}, \mathrm{O}_{2}, \mathrm{NO}_{3}(\mu \mathrm{M} / \mathrm{m})$ in the density field $\left(\sigma_{\theta}, \mathrm{kg} / \mathrm{m}^{3}\right)$.

Density layer $\sigma_{\theta}=15.85-15.95 \mathrm{~kg} / \mathrm{m}^{3}$ : In the middle of the redox zone, oxidizers diffusing from the upper layer (oxygen and nitrate) decrease to zero. This occurs simultaneously with the disappearance of reductants (ammonia, manganese (II), methane) diffusing up from the anoxic zone. A minimum of phosphate is also found here. This layer may be very thin, probably only $3-5 \mathrm{~m}$, and its position may vary over the density range specified.

The co-occurrence of the phosphate minimum and the depletion depths of ammonium, manganese and methane with the upper boundary of the FPL at the same density level suggests to the possible existence of some unifying controlling mechanism.

This common mechanism may be that the redox reactions completed with oxygen. The presence of even $1.5 \mu \mathrm{M}$ of oxygen $(50 \%$ smaller than detection limit of the voltammetric and Winkler techniques; Glazer et al., 2006) can explain the oxidation of dissolve manganese, ammonia and methane at this depth. Nitrate (which can be measured with accuracy down to $0.05 \mu \mathrm{M}$ ) is evidently also actively consumed in this layer to erratically zero. Denitrification and anammox reactions result in a decrease of total fixed nitrogen and a corresponding increase of $\mathrm{N}_{2}$ (Murray et al., 2003a). The formation of the phosphate minimum may result from its removal by scavenging Fe, Mn hydroxides (Shaffer, 1986).

Based on estimates of bacterial production within layer (Sorokin, 2002), dark chemosynthesis can consume nutrients like photosynthesis does in the euphotic zone. Intensive growth of bacteria could be another significant reason for the decrease of phosphate in the $\mathrm{PO}_{4}$ minimum, and consumption of the upward flux of ammonium. This idea is supported by the increased concentrations of urea and organic phosphorus in this layer. Burlakova et al. (1999) also showed an increase of PON in this layer. Coban-Yildiz et al. (2000) also observed an increase of PON in this layer and suggested that a significant fraction of this particulate $\mathrm{OM}$ was of bacterial origin with additional contribution from partially decayed sinking particles. The relative importance of sorption on metal oxides and chemosynthesis is not clear and needs more study.

The main result of the geochemical reactions in this layer is the formation of new oxidizers respectively, particulate oxidized manganese (III, IV) and iron (III). In addition to diffusive transport, their sinking rate can accelerate the downward transport of these electron acceptors.

Density layer $\sigma_{\theta}=16.10-16.15 \mathrm{~kg} / \mathrm{m}^{3}$ : This layer constitutes the lower part of the redox zone. The onset of hydrogen sulfide occurs just below the depths of maximum particulate manganese and iron. The reduction of particulate manganese(IV) by sulfide is very intensive (Lewis and Landing, 1991; Rozanov, 1995) and model estimates (Yakushev and Debolskaya, 2000) suggest this reaction can balance the hydrogen sulfide flux from below. 
A deeper phosphate maximum occurs about 5-10 m below the appearance of hydrogen sulfide. The vertical gradient of hydrogen sulfide increases at this depth (Fig. 5). The shape of the sulfide profile is typical for the central regions of the Black Sea distant from the Bosporus Plume and not affected by intensive vertical mixing.

\subsection{Vertical gradients}

The studies of the processes responsible for the vertical chemical structure of the redox zone are based on estimating of the vertical fluxes of reacting compounds. These fluxes are dependend on the vertical gradients and their changes with depth.

The vertical gradients of several parameters $(\mathrm{Mn}$, $\mathrm{NH}_{4}, \mathrm{H}_{2} \mathrm{~S}, \mathrm{O}_{2}, \mathrm{NO}_{3}$ ) at different density levels were calculated using data from 11 stations that were sampled in the NE BS with $2-3 \mathrm{~m}$ resolution. The following procedure was used: a spline function was fit to the data of each station. The depth gradients were then calculated using this spline function. The calculated gradients were compared with the corresponding density data. The density field was divided into $0.01 \mathrm{~kg} / \mathrm{m}^{3}$ steps. The minimum, maximum, mean and median of the various gradients were calculated for corresponding density values. The mean values of the gradients of $\mathrm{Mn}, \mathrm{NH}_{4}, \mathrm{H}_{2} \mathrm{~S}, \mathrm{O}_{2}$, $\mathrm{NO}_{3}$ are presented versus density in Fig. 5.

These calculations show that the vertical gradient of dissolved oxygen has a maximum of $7-10 \mu \mathrm{M} / \mathrm{m}$ in the oxycline $\left(\sigma_{\theta} \approx 15.0 \mathrm{~kg} / \mathrm{m}^{3}\right)$. In the layer of $\sigma_{\theta}=15.8-16.0 \mathrm{~kg} / \mathrm{m}^{3}$, the oxygen gradients decrease to $0.1-0.4 \mu \mathrm{M} / \mathrm{m}$. The vertical gradient of nitrate is equal to or greater than the vertical gradient of oxygen below $\sigma_{\theta}=15.6-15.7 \mathrm{~kg} / \mathrm{m}^{3}$ (Fig. 5). Shallower than $15.6-15.7 \mathrm{~kg} / \mathrm{m}^{3}$, the nitrate gradient decreases sharply (from values about $1 \mu \mathrm{M} / \mathrm{m}$ ) and above the nitrate maximum $\left(15.3-15.5 \mathrm{~kg} / \mathrm{m}^{3}\right)$ changes sign. Vertical gradients of hydrogen sulfide are characterized by maximum values (up to $0.5-0.9 \mu \mathrm{M} / \mathrm{m})$ in the layer $\sigma_{\theta}=16.2-16.6 \mathrm{~kg} / \mathrm{m}^{3}$, but near the depth of hydrogen sulfide onset, the vertical gradient of this parameter decreases to $0.15-0.20 \mu \mathrm{M} / \mathrm{m}$ or less. The change in the vertical gradient of hydrogen sulfide from $0.6-0.7$ to $0.15-0.20 \mu \mathrm{M} / \mathrm{m}$ coincided with the lower boundary of the FPL, which corresponded to the depth of phosphate maximum (Figs. 2 and 3). Vertical gradients of manganese have maximum values $(0.10-0.15 \mu \mathrm{M} / \mathrm{m})$ at about the onset of $\mathrm{H}_{2} \mathrm{~S}$ $\left(\sigma_{\theta}=16.0-16.2 \mathrm{~kg} / \mathrm{m}^{3}\right)$. The Mn gradient decreased in deeper layers. The vertical gradient of ammonia was also characterized by maximum values of $0.11-0.15 \mu \mathrm{M} / \mathrm{m}$ in the layer $\sigma_{\theta}=16.0-16.2 \mathrm{~kg} / \mathrm{m}^{3}$.

The main result of these calculations is that at specific density levels in the redox layer the vertical gradients of chemical parameters are characterized by constant values. At the same time, the vertical gradients of every parameter change following the changes of density (Fig. 5). These layers where the vertical gradients change versus density (depth) should correspond to the existence of layers of specific sources or sinks.

\subsection{Model estimates of the rates of changes of concentrations}

The vertical distributions of concentrations and gradients of a certain parameter can be used for the estimating "sources" or "sinks" $R_{i}$ of this parameter that compensate the changes connected with vertical diffusion. As mentioned above, in the NE BS we do not observe significant horizontal changes of concentrations and that allowed us to use the following 1D formula:

$R_{i}=\frac{\partial}{\partial z}\left(k \frac{\partial c_{i}}{\partial z}\right)=\frac{\partial k}{\partial z} \frac{\partial c_{i}}{\partial z}+k \frac{\partial^{2} c_{i}}{\partial z^{2}}$,

where $k$ is the vertical turbulent exchange coefficient and $c_{i}$ is a concentration of a component under study.

We applied this formula for the nitrogen compounds because we measured four forms of them $\left(\mathrm{NO}_{2}, \mathrm{NO}_{3}, \mathrm{NH}_{4}\right.$, Urea). Nitrogen is a good example to use to compare the values and depths of the source terms $\left(R_{i}\right)$.

The results of such estimates depend upon vertical variability in the turbulent exchange coefficient $k$. Estimates of $k(z)$ were obtained using a 3D numerical model (Debolskaya, 2002) that included equations of: (1) motion for the conditions of baroclinity, (2) continuity, (3) transfer for kinetic turbulence energy with consideration of the buoyancy force and (4) vertical transfer of multiplication of kinetic energy by scale of turbulence. The basis of the model are measured temperature and salinity data.

We determined the density distribution during $R / V$ "Akvanavt" St. 783 (September 2001) and 1331 (June 2002) using CTD measurements made with a vertical resolution of $20 \mathrm{~cm}$. This allowed us to obtain a detailed profile of the vertical diffusion coefficient $k$. The values of $k$ obtained were about 
$2 \times 10^{-5} \mathrm{~m}^{2} / \mathrm{s}$ at the depth of the hydrogen sulfide boundary. Similar values for this coefficient at the hydrogen sulfide boundary depth were obtained by Stokozov (2004), who analyzed spreading of ${ }^{137} \mathrm{Cs}$ after the Chernobyl accident. He determined values for $k$ of $1-3 \times 10^{-5}$ in the Black Sea Central Basin and $3-11 \times 10^{-5} \mathrm{~m}^{2} / \mathrm{s}$ in the region of the RIM current.

For the source/sink calculations we used data for $\mathrm{NO}_{2}, \mathrm{NO}_{3}, \mathrm{NH}_{4}$, urea, which were sampled at the same stations with vertical resolution of $2-5 \mathrm{~m}$ (Yakushev et al., 2003). The results of these "source" calculations are presented in Fig. 6. The magnitude of $R_{i}$ should be balanced by chemicalbiological transformations. From these results we can see that in the vicinity of onset of ammonium the magnitude of $R_{i}$ is large from 120 to $150 \mathrm{~m}$ with maximum at $140 \mathrm{~m}$ at St. 783 and from 130 to $160 \mathrm{~m}$ with maximum at $150 \mathrm{~m}$ at St. 1331. Biochemical process should result in consumption of ammonium at a rate up to $0.3 \mu \mathrm{M} / \mathrm{d}$. At slightly deeper depths, nitrate is consumed at a rate of $0.3-0.4 \mu \mathrm{M} / \mathrm{d}$ from 130 to $150 \mathrm{~m}$ with a maximum at $145 \mathrm{~m}$ at St. 783 and from 130 to $160 \mathrm{~m}$ with a maximum at $150 \mathrm{~m}$ at St. 1331. In the central part of the nitrate maximum $(100-120 \mathrm{~m}$ at St. 783 and $100-130 \mathrm{~m}$ at St.1331), the biogeochemical processes of nitrate production dominate with a rate of $0.4-0.7 \mu \mathrm{M} / \mathrm{d}$. Consumption of nitrate $(0.4-0.5 \mu \mathrm{M} / \mathrm{d}$ at St. 783 and $0.1-0.2 \mu \mathrm{M} / \mathrm{d}$ at St. 1331) is intensive again in the upper part of oxycline $(\sim 80 \mathrm{~m})$, possibly due to biological uptake by primary production. A small maximum in production of nitrate $(0.01-0.02 \mu \mathrm{M} / \mathrm{d})$ was found at both stations directly at the depth of the maximum ammonia consumption.

With this model we can estimate (in $\mathrm{N}$ units) the maximum values of sources and sinks at the oxic/ anoxic interface. Practically, these sources $\left(R_{i}\right)$ reflect differences in the intensities of processes of production and consumption. Therefore, above the hydrogen sulfide boundary there is sink of nitrate $(\sim 0.2-0.4 \mu \mathrm{M} / \mathrm{d})$ and ammonium $(\sim 0.3 \mu \mathrm{M} / \mathrm{d})$. In this layer in the deeper part of the suboxic zone, nitrate becomes the dominant oxidizer as seen in the comparison of the vertical gradients of oxygen and nitrate (Fig. 5). Nitrate can be consumed by denitrification and reduction by thiosulfate, elemental sulfur and sulfide (Nealson and Stahl, 1997). Nitrite that is producing can be used for the anammox reaction (Murray et al., 2003a), which is mediated by bacteria found in the Black Sea (Kuypers et al., 2003). The role of nitrate as a potential oxidizer of reduced manganese and iron has been discussed (Murray et al., 1995; Luther et al., 1997), but the presence of these reactions has yet to be confirmed.

Another possible sink of inorganic nitrogen compounds is consumption by OM synthesis. As seen from the urea transformation rates, the intensity of $\mathrm{OM}$ formation and decay can be on
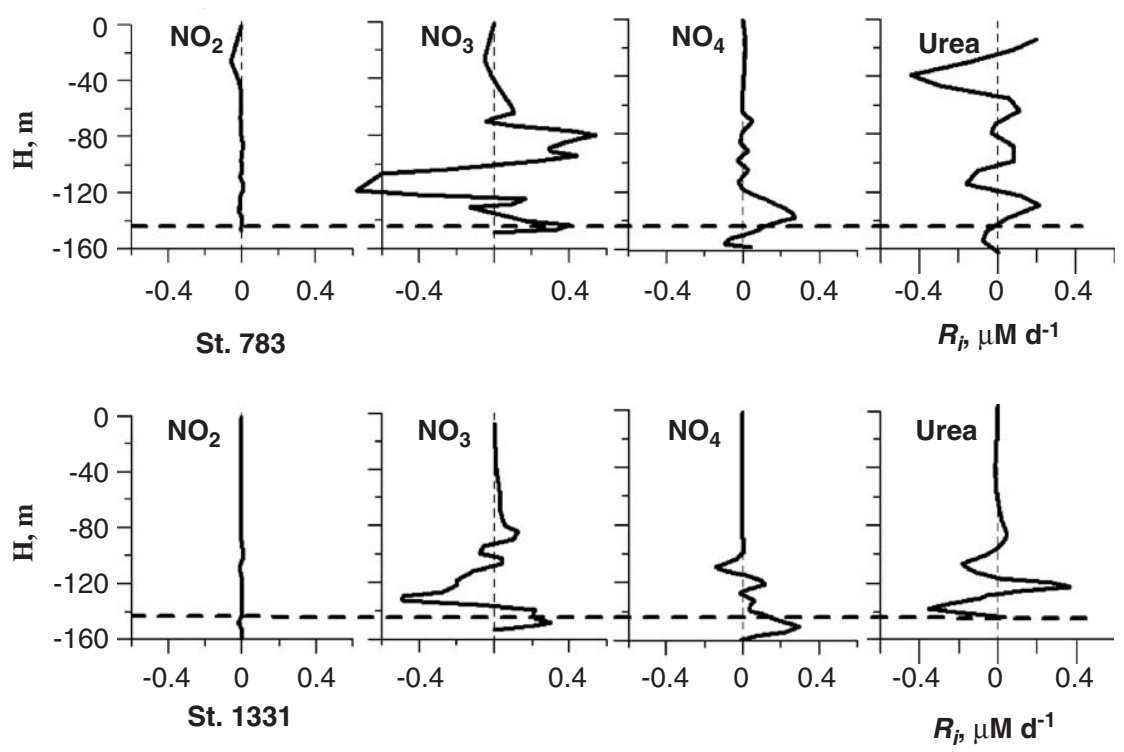

Fig. 6. Vertical distribution of "sources" $R_{i}$ connected with processes of vertical turbulent exchange for $\mathrm{NO}_{2}, \mathrm{NO}_{3}, \mathrm{NH}_{4}$ and urea at stations 783 and 1331. The dashed line is the hydrogen sulfide boundary position. 
the same order of magnitude as the processes that consume and produce ammonium and nitrate $(0.2-0.4 \mu \mathrm{M} / \mathrm{d})$, but the maxima in urea production/consumption are offset from those for nitrate and ammonia.

Maximum values of dark $\mathrm{CO}_{2}$ fixation rates in the vicinity of sulfide boundary in the central Western Gyre have been measured as $5 \mu \mathrm{g} \mathrm{C} / \mathrm{L} / \mathrm{d}$ (Yilmaz et al., 2006), 2.3-7.7 $\mu \mathrm{g} \mathrm{C} / \mathrm{Ld}$ (Morgan et al., 2006) and $10 \mu \mathrm{g} \mathrm{C} / \mathrm{Ld}$ in the central and coastal NE BS (Pimenov and Neretin, 2006). Assuming an uptake ratio of $\mathrm{C} / \mathrm{N}=6.6$, these values correspond to $0.06-0.12 \mu \mathrm{MN} / \mathrm{d}$. Therefore, the sinks calculated from the model cannot be explained only by consumption by chemosynthesis.

With this simple model, it is also possible to demonstrate that the sources and sinks of matter resulting from the vertical turbulent exchange should also correspond to specific density levels as observed.

\subsection{Seasonal variability}

Studies of the seasonal variability of parameters are difficult since datasets of winter hydrochemical measurements are very rare compared with those of the summer. Winter features of the suboxic layer structure were studied with fine resolution during $R / V$ "Akvanavt" cruises in December 2001, 2002, 2004 (Table 1) and the $R / V$ "Knorr" cruise in March 2003. Results of winter observations obtained in the NE BS coastal waters on January 26, 2004 (St. \#1487 R/V "Akvanavt" cruise \#57) are shown in Fig. 3. The location of station \#1487 relative to the geostrophic current field is shown in Fig. 1. The geostrophic currents were calculated using hydrophysical data collected during the first stage of this cruise (January 24-26, 2004). St.1487 was situated near an anticyclonic eddy (Fig. 1) in a region with increased horizontal velocities in the redox layer. The intensity of mixing in the redox layer at this station was greater than in the surrounding waters.

The main differences between summer and winter distribution (Figs. 2 and 3), can be summarized as following:

- The vertical distribution of phosphate in the winter was characterized by absence of the shallower minimum.

- The concentrations of nitrate at the nitrate maximum were lower in winter $(2.5 \mu \mathrm{M})$ than in other times of the year $(>4.5 \mu \mathrm{M})$.
- The maxima of organic phosphorus and urea content at the onset of hydrogen sulfide, which are typically observed in summer, were absent in the winter. The concentrations of organic nitrogen were lower in winter than in summer (organic nitrogen is not shown in Fig. 2, but we have observed larger organic nitrogen values in some other summer stations).

- Alkalinity was uniformly distributed to $\sigma_{\theta}=15.90 \mathrm{~kg} / \mathrm{m}^{3}$ in summer (similar to that observed by Hiscock and Millero, 2006) and increased gradually below the depth of the CIL in winter.

- Changes of the vertical gradients of hydrogen sulfide, ammonium, manganese and methane at their onset depths were smoother in the winter than in summer.

We found that one of the tracers of the seasonal variability estimates was the shape of the vertical phosphate distribution. The phosphate maximum/ minimum dipole observed in the summer was not observed in our winter data (December, January) from eddies near the NE BS coast.

For better understanding of the seasonal variability of phosphate, we performed statistical analysis of seasonal variability of the shallower phosphate minimum in the northeastern part of the Black Sea (Yakushev et al., 2005). Coastal zone (up to about $70 \mathrm{~km}$ from the shore) stations and open sea zone $(70-180 \mathrm{~km})$ stations were examined separately. The density layer of $15.80-15.90 \mathrm{~kg} / \mathrm{m}^{3}$ was used for analysis, since the minimum of the phosphate that appears just above the suboxic zone falls into this interval.

According to this statistical analysis (Fig. 7), concentrations of phosphate in the minimum in the northeastern part of the Black Sea are higher at the coast than in the open sea during both winter and summer periods. Our data do not show distinct seasonal variability in the open sea stations, but there are few winter datasets. At the coastal stations, phosphate concentrations during the winter were greater than in summer by $0.2-0.5 \mu \mathrm{M}$, and showed an increasing trend during the winter periods from 2001 to 2004 (from $0.8-1$ to $1.2-1.6 \mu \mathrm{M})$.

Two factors could affect the seasonal variability of the hydrochemical structure of the oxic/anoxic interface: seasonality of $\mathrm{OM}$ production and seasonality of the intensity of vertical mixing. A decrease of OM flux in the winter could result in a 

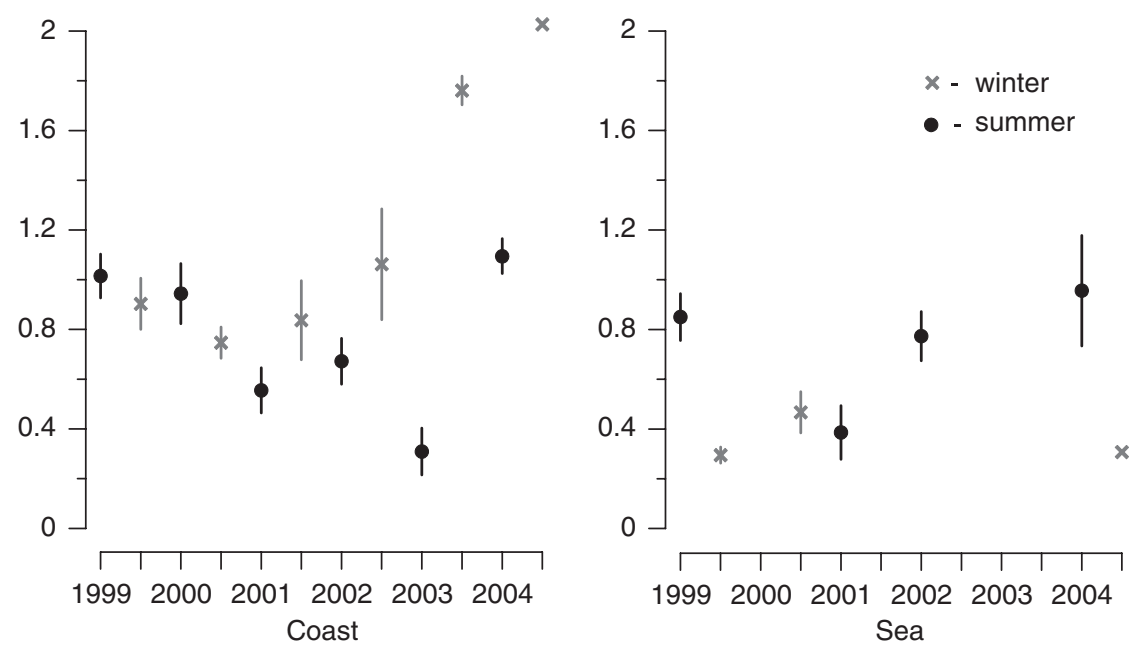

Fig. 7. Results of statistical analysis of mean observation of the phosphate in the density layer of $\sigma_{\theta}=15.8-15.9 \mathrm{~kg} / \mathrm{m}^{3}$. Calculations in the coastal area (0-70 km from the shore) are shown on the left part, and open sea part is shown on the right. Vertical line displays the value of standard deviation.

decrease in the concentrations of bacteria and could slow the rates of heterotrophic biogeochemical transformation. This decrease in the number of bacteria and reduction of the rates of reactions was described by Sorokin et al. (1992). Enhanced mixing associated with anticyclonic eddies in the winter leads to smoothing of the vertical gradients and extrema resulting in changes in biogeochemical reactions such as formation of the phosphate dipole (due both to the consumption for OM and for precipitation with the metal hydroxides).

\subsection{Interannual variability}

Chemotropy gives us a unique opportunity for comparison and statistical analysis of data acquired in different regions and seasons on different expeditions. We used unique series of data from the NE BS to estimate the changes of the position of the boundaries of the anoxic zone.

We choose the Akima spline technique for these calculations because it gave results which were easier to reproduce. Data from every station were analyzed individually. Results of these calculations for monthly averaged intervals (in some months we had two or three small cruises, see Table 1) are shown in Fig. 8. The data shown in Fig. 8 are the oxygen concentrations at $\sigma_{\theta}=14.45-14.60 \mathrm{~kg} / \mathrm{m}^{3}$ and the density of first appearance of sulfide, ammonium, manganese and methane.

The values obtained differed slightly (without a systematic bias) from estimates that were reported by other authors who used visual or linear regression methods for estimating the onset values (Vinogradov and Nalbandov, 1990; Murray et al., 1995; Volkov et al., 1997; Chasovnikov, 2002). Values for methane were deeper than reported by Egorov (2002), because the vertical gradient of methane decreases gradually in the vicinity of the onset point.

These results show that the depth of onset of hydrogen sulfide occurred at values of $\sigma_{\theta}=$ $16.15-16.25 \mathrm{~kg} / \mathrm{m}^{3}$ in $1991-1998$ (Fig. 8). In 1999 2000 , this boundary shoaled to about $\sigma_{\theta}=16.05$ $16.15 \mathrm{~kg} / \mathrm{m}^{3}$ (corresponding to a depth change of about 5-15 m). After 2000, the density of hydrogen sulfide onset stabilized. A similar upward shift was observed for other reductants - ammonia, total manganese and methane. These changes between $1998 / 1999$ may be related to the two warm winters that occurred in 1998-1999. These years were distinguished by an increase of sea surface temperature (Fig. 8) and an increase of temperature in the core of the CIL (Krivosheya et al., 2002; Oguz et al., 2006).

A decrease in intensity of CIL formation should lead to an increase of its core temperature and a decrease of its oxygen content. To confirm this we calculated average concentrations of dissolved oxygen in the CIL (defined as the layer from $\sigma_{\theta}=14.45 \mathrm{~kg} / \mathrm{m}^{3}$ to $\left.-\sigma_{\theta}=14.60 \mathrm{~kg} / \mathrm{m}^{3}\right)$. These calculations should reflect both changes of concentrations in the CIL and vertical shifts of the core of the CIL in the density field (Murray et al., 2003a, b). In 


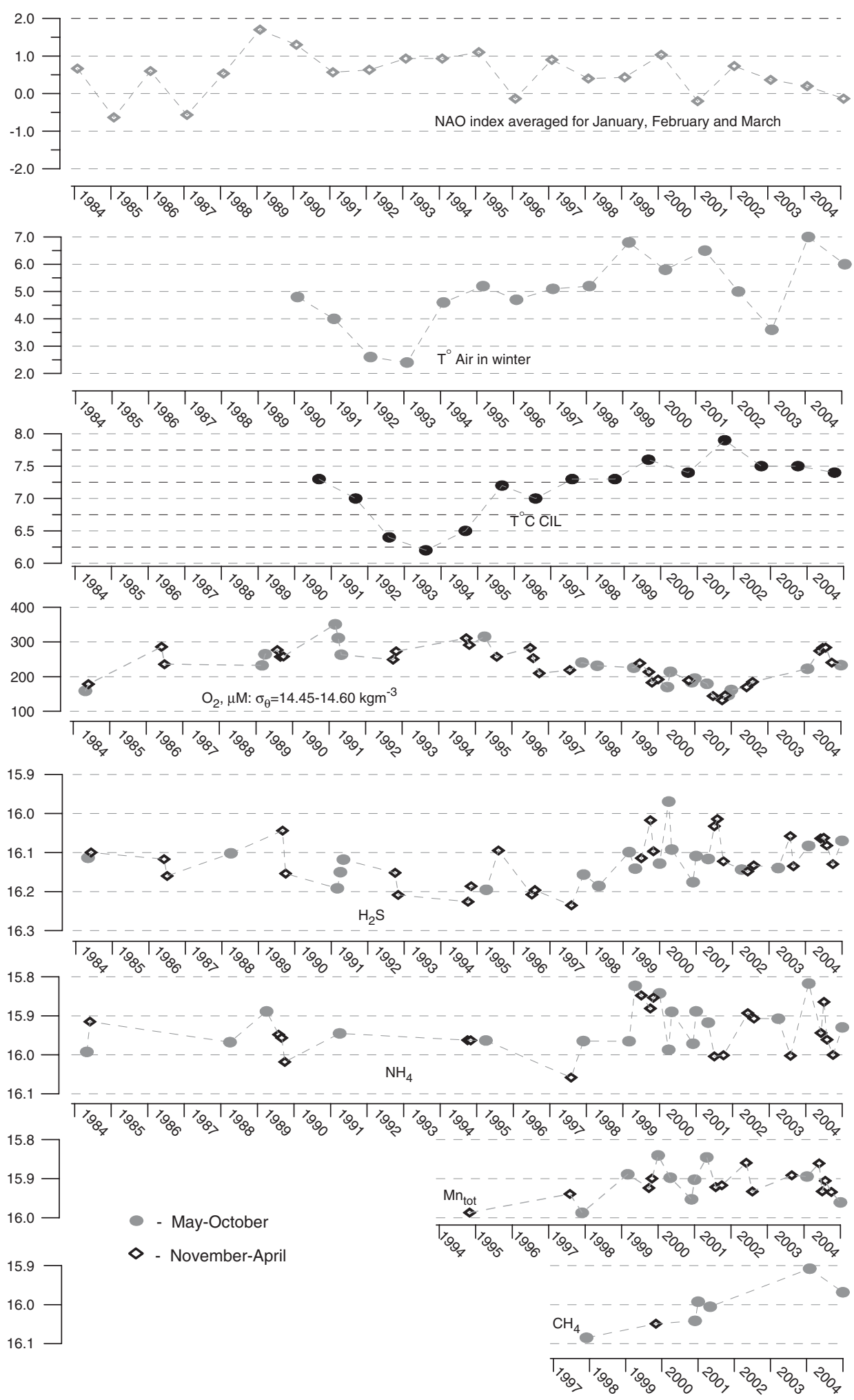

Fig. 8. Interannual variability of the winter NAO index (averaged for November-February), winter air temperature in Gelendzhik, temperature in CIL core in the Northeastern Black Sea (data of V.G. Krivosheya), the averaged content of oxygen in the CIL $\left(\sigma_{\theta}=14.45-14.60 \mathrm{~kg} / \mathrm{m}^{3}\right)$ and onsets in the density field $\left(\sigma_{\theta}, \mathrm{kg} / \mathrm{m}^{3}\right)$ of hydrogen sulfide, total manganese, ammonia and methane. 
1999-2000, after the shoaling occurred for several reductants, a decrease in the oxygen content was observed. Minimum $\mathrm{O}_{2}$ concentrations $(\sim 150 \mu \mathrm{M})$ were observed in 2001-2002. In 2003-2004, the oxygen content in this layer increased to the values ( $>200 \mu \mathrm{M}$ ) typical for the beginning of the 1990s.

All these events may be connected with oscillations of weather conditions associated with oscillations in the North Atlantic Oscillation (NAO) (Fig. 8). An index averaged for the winter months (November-February) was characterized by relatively high values in 1993-1995, when the highest oxygen content in the CIL and lowest sulfide boundary position were observed.

These results suggest clues for how the distributions in the Black Sea may change in response to future climate change. An increase in sea-surface temperature may lead to a reduction in the rate of formation of CIL water in the winter and which would result in less replenishment of its oxygen content. The inventory of oxygen in the CIL integrates the balance between the annual consumption of oxygen by respiration of the downward flux $\mathrm{OM}$ and the replenishment of oxygen by ventilation. The interannual variations of oxygen renovation in the CIL lead to changes in the hydrochemical structure (Konovalov and Murray, 2001). In particular, this leads to changes in the density of the upper boundary of the suboxic zone. Therefore, changes in the distribution of chemical parameters versus density is an excellent indicator of the variability due to climate forcing. In particular, the position of the redox zone and anoxic boundary in the density field reflects oscillations of the volume of oxic and anoxic waters produced in the Sea.

\section{Conclusions}

Changes in chemotropy versus time (seasonal, interannual) in the redox zone of the NE BS suggest that this system is balanced at steady state. We determined that the vertical gradients of certain chemical parameters are constant at specific density levels, and that the values of the vertical gradients of every parameter change following the changes of density. These layers, where vertical gradients regularly change with depth, correspond to the existence of layers with source or sink of matter. Using a simple model we showed that these sources and sinks resulted from the vertical turbulent exchange which corresponds to the specific density levels. Therefore, in addition to the connection of positions of extrema and onset points of chemical parameters with density, the connection between the vertical gradients and sources of matter with density is also a feature of the chemotropic structure.

The biogeochemical distributions in the redox layer of the Black Sea, even in the most stable northeastern part, are subject to changes on different time scales. Seasonal variability in the distribution of the chemical parameters in the redox interface may be connected to the seasonal changes of OM production and consumption. In winter, the maxima of organic phosphorus and urea were absent in the winter in the vicinity of the onset of hydrogen sulfide. The concentrations of nitrate were lower in the winter. Enhanced mixing in anticyclone eddies leads to decreasing of vertical gradients and to the disappearance of the upper phosphate minimum in local spots.

Interannual changes occur in the density of first appearance of hydrogen sulfide. These changes are correlated with changes in the NAO index suggesting a link to climate change. The density structure of a redox layer appears to be a good indicator of the natural climate-related oscillations. The result of $5-10 \mathrm{~m}$ oscillations in the anoxic boundary is that the volume of surface oxic waters, where the Black Sea oxic ecosystem is situated is reduced by about $5-10 \%$.

\section{Acknowledgements}

We would like to thank our colleagues: V.P. Chjou, N.L. Kuprikova, N.M. Menshikova, E.A. Antipova and O.I. Podymova for the help with field data sampling and analytical measurements. We thank Clara Fuchsman for discussion of this paper and corrections of the text. J.W. Murray reviewed and edited the manuscript. This work was supported by Russian Ministry of Science and Technology Federal Purposeful Program "The World Ocean", CRDF project RGI-2388-GE-02, SNSF Project 7SUPJ062194 and by the Russian Foundation for Basic Research Grants No. 02-05-64762, 02-05-65098, 03-05-96668-r2003yug, 05-05-65092-a.

\section{References}

Bol'shakov, A.M., Egorov, A.V., 1987. Using of phase-equilibrium degassing method for gasometrical studies. Oceanology 27, 861-862 (English translation).

Bordovskiy, O.K., Chernyakova, A.M. (Eds.), 1992. Modern Methods of the Ocean Hydrochemical Investigations. 
P.P. Shirshov Institute of Oceanology, Moscow, p. 200 (In Russian).

Brewer, P.G., Spencer, D.W., 1971. Colorimetric determination of manganese in anoxic waters. Limnology and Oceanography $16(1), 107-110$.

Burlakova, Z.P., Eremeeva, L.I., Konovalov, S.K., 1999. Seasonal and spatial variability of the content of suspended organic substances in the active layer of the Black Sea. Physical Oceanography 10, 419-454.

Chasovnikov, V.K., 2002. Peculiarities of the hydrochemical structure of the northeastern part of the Black Sea. Ph.D. Thesis, Shirshov Institute of Oceanology, Moscow, pp. 125.

Coban-Yildiz, Y., Chiavari, G., Fabbri, D., Gaines, A.F., Galetti, G., Turgul, S., 2000. The chemical composition of Black Sea suspended particulate organic matter; pyrolis GC/ MS as a complementary tool to traditional oceanographic analysis. Marine Chemistry 69, 55-67.

Cociasu, A., Dorogan, L., Humborg, C., Popa, L., 1996. Longterm ecological changes in the Romanian coastal waters of the Black Sea. Marine Pollution Bulletin 32, 32-38.

Codispoti, L.A., Friederich, G.E., Murray, J.W., Sakamoto, C.M., 1991. Chemical variability in the Black Sea: implication of continuous vertical profiles that penetrated oxic/anoxic interface. Deep-Sea Research 38 (2), S691-S710.

Debolskaya, E.I., 2002. Analysis of the Black Sea redox zone turbulent structure in the Black Sea based on the $R / V$ "Akvanavt" 18th cruise data. Modern notion of the vertical hydrochemical structure of the Black Sea redox zone. In: Zatsepin, A.G., Flint, M.V. (Eds.), Complex Investigation of the Northeastern Black Sea, Nauka, Moscow, pp. 140-150 (In Russian).

Egorov, A.V., 2002. On distribution of methane in the Black Sea water column. In: Zatsepin, A.G., Flint, M.V. (Eds.), Complex Investigation of the Northeastern Black Sea. Nauka, Moscow, pp. 144-147 (In Russian).

Glazer, B.T., Luther III, G.W., Konovalov, S.K., Friederich, G.E., Trouwborst, R.E., Romanov, A.S., 2006. Spatial and temporal variability of the Black Sea suboxic zone. Deep-Sea Research II, this issue [doi:10.1016/j.dsr2.2006.03.022].

Hansen, H.P., 1999. Determination of oxygen. In: Grashoff, K., Kremling, K., Ehrhard, M. (Eds.), Methods of Seawater Analysis. 3d, Completely Revised and Extended Edition. Wiley-VCH, Weinheim, NewYork, Chichester, Brisbane, Singapore, Toronto, pp. 75-90.

Hansen, H.P., Koroleff, F., 1999. Determination of nutrients. In: Grashoff, K., Kremling, K., Ehrhard, M. (Eds.), Methods of Seawater Analysis. 3d, completely revised and extended edition. Wiley-VCH, Weinheim, NewYork, Chichester, Brisbane, Singapore, Toronto, pp. 149-228.

Hiscock, W.T., Millero, F.J., 2006. Alkalinity of the Anoxic Waters in the western Black Sea. Deep-Sea Research II, this issue [doi:10.1016/j.dsr2.2006.05.020].

Ivanov, L.I., Konovalov, S., Belokopytov, V., Ozsoy, E., 1999. Regional peculiarities of physical and chemical responses to changes in external conditions within the Black Sea pycnoclyne: cooling phase. In: Besiktepe, S.T., Unluata, U., Bologa, A.S. (Eds.), Environmental Degradation of the Black Sea: Challenges and Remedies, vol. 2. Kluwer Academic Publishers, Dordrecht, pp. 53-68.

Konovalov, S.K., 2001. Suboxic zone of the Black Sea: genesis and role in formation of the spatial and temporal variability of the biogeochemical structure of the waters of main pycnocline. Ph.D. Thesis, Abstract, Marine Hydrophysical Institute, Sevastopol, p. 36.

Konovalov, S.K., Murray, J.W., 2001. Variations in the chemistry of the Black Sea on a time scale of decades. Journal of Marine Sciences 31, 217-243.

Konovalov, S.K., Luther, G.W., Friederich, G.E., Nuzzio, D.B., Tebo, B.M., Murray, J.W., Oguz, T., Glazer, B., Trouwborst, R.E., Clement, B., Murray, J.W., Romanov, A.S., 2003. Lateral injection of oxygen with the Bosporus plume - fingers of oxidizing potential in the Black Sea. Limnology and Oceanography 48 (6), 2369-2376.

Koroleff, F., 1972. Determination of reactive silicate. Cooperative research report JCES Series A 29, 87-90.

Krivosheya, V.G., Ovchinnikov, I.M., Skirta, A.Yu., 2002. Intraannual variability of the cold intermediate layer of the Black Sea. In: Zatsepin, A.G., Flint, M.V. (Eds.), Complex Investigation of the Northeastern Black Sea. Nauka, Moscow, pp. 27-39.

Kuypers, M.M.M., Sliekers, A.O., Lavik, G., Schmid, M., Jorgensen, B.B., Kuenen, J.G., Sinnenghe Damste, J.S., Strous, M., Jetten, M.S.M., 2003. Anaerobic ammonium oxidation by anammox bacteria in the Black Sea. Nature 422, 608-611.

Lewis, B.L., Landing, W.M., 1991. The biogeochemistry of manganese and iron in the Black Sea. Deep-Sea Research 38 (Suppl. 2A), S773-S804.

Luther III, G.W., Church, T.M., Powel, D., 1991. Sulfur speciation and sulfide oxidation in the water column of the Black Sea. Deep-Sea Research 38 (Suppl. 2A), S1121-S1137.

Luther III, G.W., Sundby, B., Lewis, B.L., Brendel, P.J., Silverberg, N., 1997. The interaction of manganese with the nitrogen cycle in continental margin sediments: Alternative pathways for dinitrogen formation. Geochimica et Cosmochimica Acta 61, 4043-4052.

Millero, F.J., 1991. The oxidation of $\mathrm{H}_{2} \mathrm{~S}$ in the Chesapeake Bay. Estuarine and Coastal Shelf Science 33, 521-527.

Morgan, J.A., Quinby, H.L., Ducklow, H.W., 2006. Bacterial abundance and production in the Western Black Sea. DeepSea Research II, this issue [doi:10.1016/j.dsr2.2006.03.023].

Murray, J.W., Jannasch, H.W., Honjo, S., Anderson, R.F., Reeburgh, W.S., Top, Z., Friederich, G.E., Codispoti, L.A., Izdar, E., 1989. Unexpected changes in the oxic/anoxic interface in the Black Sea. Nature 338, 411-413.

Murray, J.W., Top, Z., Ozsoy, E., 1991. Hydrographic properties and ventilation of the Black Sea. Deep-Sea Research 38 (Suppl. 2A), S663-S690.

Murray, J.W., Codispoti, L.A., Friederich, G.E., 1995. The suboxic zone in the Black Sea. In: Huang, C.P., O'Melia, R., Morgan, J.J. (Eds.), Aquatic chemistry: interfacial and interspecies processes. Adv. Chem. Ser. 244. American Chemical Society, Washington DC, pp. 157-176.

Murray, J.W., Konovalov, S.K., Callahan, A., 2003a. Nitrogen reactions in the suboxic zone of the Black Sea: new data and models based on the KNORR 2001 cruise. In: Yilmaz, A. (Ed.), Oceanography of the Eastern Mediterranean and Black Sea. Proceeding of the Second International Conference on Oceanography of the Eastern Mediterranean and Black Sea: Similarities and Differences of Two Interconnected Basins, TUBITAK Publishers, Ankara, Turkey, pp. 591-602.

Murray, J.W., Fuchsman C., Kirpatrick J., Paul B., Konovalov, S.K., Callahan, A., 2003b. Nitrogen transformations in the suboxic zone of the Black Sea. Nitrogen reactions in the suboxic zone of the Black Sea. Oceanography, 18(2), 36-47. 
Nealson, K.N., Stahl, D.A., 1997. Microorganisms and biogeochemical cycles: what can be learn from layered microbial communities? In: Banfield, J.F., Nealson, K.N. (Eds.), Reviews in mineralogy 35, Geomicrobiology: Interactions between Microbes and Minerals. Mineralogical Society of America, Washington, DC, pp. 5-34.

Oguz, T., Dippner, J.W., Kaymaz, Z., 2006. Climate regulation of the Black Sea hydro-meteorological and ecological properties at interannual-to-decadal time scales. Journal of Marine Systems, submitted for publication.

Peshkova, V.M., Ovsyannikova, A.A., 1937. Colorimetric determination of manganese using formaldoxime. Zavodskaya Laboratoriya 7, 800-803 (In Russian).

Pimenov, N.G., Neretin, L.N., 2006. Composition and activities of microbial communities, involved in carbon, sulfur, nitrogen and manganese cycling in the oxic/anoxic interface of the Black Sea. In: Neretin, L.N. (Ed.), Past and Present Water Column Anoxia. In NATO Sciences Series, Springer, Berlin, pp. 501-522.

Podymov, O.I., 2005. Numerical estimates of the hydrochemical characteristics of the Black Sea redox layer with a problem oriented data base. Ph.D. Thesis, Shirshov Institute of Oceanology, Moscow, p. 115.

Rozanov, A.G., 1995. Redox stratification of the Black Sea water. Oceanology 35, 544-549.

Rozanov, A.G., Demidova, T.P., Egorov, A.V., Lukashev, Yu.F., Stepanov, N.V., Chasovnikov, V.K., Yakushev, E.V., 2000. Hydrochemical structure of the Black Sea at the standard section from Gelendzhik to the central part of the Sea (November 1997). Oceanology 40, 30-36.

Sapozhnikov, V.V., Agatova, A.I., Arzhanova, N.V., 1988. Methods of hydrochemical investigations of the main nutrients. Ed. VNIRO, Moscow, p. 119.

Shaffer, G., 1986. Phosphorus pumps and shuttles in the Black Sea. Letters to Nature 321, 515-517.

Solorzano, Z., 1969. Determination of ammonium in natural water by the phenohypochlorite method. Limnology and Oceanography 14, 799-801.

Sorokin, Yu.I., 2002. The Black Sea. Ecology and Oceanography. Backhuys Publishers, Leiden, (875pp).

Sorokin, Yu.I., Sorokin, P.Yu., Sorokina, O.V., Sorokin, D.Yu., Sukhomlin, A.V., 1992. Distribution and the functional activity of the microflora in the water thickness of the Black Sea in winter and beginning of spring 1991. In: Vinogradov, M.E. (Ed.), Winter State of the Ecosystem of the Open Part of the Black Sea. Shirshov Institute of Oceanology RAS, Moscow, pp. 89-102.

Stokozov, N.A., 2004. Long-lived radionuclides 137Cs and 90Sr in the Black Sea after the Chernobyl NPP accident and their use as a tracers of water exchange processes. Ph.D. Thesis, Sebastopol, MHI, 2004, $21 \mathrm{pp}$.

Stookey, L.L., 1970. Ferrozine: a new spectrophotometric reagent for iron. Analytical Chemistry 42, 779-781.
Tebo, B.M., 1991. Manganese(II) oxidation in the suboxic zone of the Black Sea. Deep-Sea Research 38 (Suppl. 2), 883-905.

Turgul, S., Basturk, O., Saydam, C., Yilmaz, A., 1992. Changes in the hydrochemistry of the Black Sea inferred from water density profiles. Nature 359, 137-139.

Vinogradov, M.E., Nalbandov, Yu.P., 1990. Dependence of physical, chemical and biological parameters in pelagic ecosystem of the Black Sea upon the water density. Oceanology 30, 769-777.

Volkov, I.I., Zhabina, N.N., 1990. A method of definition of the reduced compounds of sulfur in the sea water. Oceanology 30 , 778-782 (in Russian).

Volkov, I.I., Kontar', E.A., Lukashev, Yu.F., Neretin, L.N., Nyffeler, F., Rozanov, A.G., 1997. Upper boundary of the hydrogen sulfide and the nature of the Nepheloid Redox Layer in the waters of the Caucasian Slope of the Black Sea. Geochemistry International 6, 618-629.

Yakushev, E.V., Debolskaya, E.I., 2000. Particulate manganese as a main factor of oxidation of hydrogen sulfide in redox zone of the Black Sea. In: Oceanic Fronts and Related Phenomena. Konstantin Fedorov Memorial Symposium. Pushkin, Saint-Petersburg, Russia, 18-22 May, 1998, Proceedings. IOC Workshop Report No. 159, Kluwer Academic Publishers, Dordrecht, 2000, pp. 592-597.

Yakushev, E.V., Besedin, D.E., Lukashev, Yu.F., Chasovnikov, V.K., 2001. On the upward shift of the boundary of anoxic zone in the density field in the Black ea in 1999-2000. Oceanology 41, 686-691 (English Translation).

Yakushev, E.V., Lukashev, Yu.F., Chasovnikov, V.K., Chzhu, V.P., 2002. Modern notion of the vertical hydrochemical structure of the Black Sea redox zone. In: Zatsepin, A.G., Flint, M.V. (Eds.), Complex Investigation of the Northeastern Black Sea. Nauka, Moscow, pp. 119-133 (In Russian).

Yakushev, E.V., Chasovnikov, V.K., Debolskaya, E.I., Gregoire, M., Podymov, O.I., Yakubenko, V.G., 2003. The northeastern Black Sea redox zone hydrochemical structure: observed concentrations and estimated fluxes. In: Yilmaz, A. (Ed.), Oceanography of the Eastern Mediterranean and Black Sea. Tubitak Publishers, Ankara, pp. 322-328.

Yakushev, E.V., Podymov, O.I., Chasovnikov, V.K., 2005. Seasonal changes in hydrochemical structure of the Black Sea redox zone. Oceanography 18 (2), 44-51.

Yilmaz, A., Coban-Yildiz, Y., Telli-Karakoc, F., Bologa, A., 2006. Surface and mid-water sources of organic carbon by photo- and chemoautotrophic production in the Black Sea. Deep-Sea Research II, this issue [doi:10.1016/j.dsr2. 2006.03.015].

Zatsepin, A.G., Kremenetskiy, V.V., Poyarkov, S.G., Ratner, Yu.B., Stanichny, S.V., 2002. Influence of wind field on water circulation in the Black Sea. In: Zatsepin, A.G., Flint, M.V. (Eds.), Complex Investigation of the Northeastern Black Sea. Nauka, Moscow, pp. 91-105 (In Russian). 